Anuario de la Facultad de Derecho. Universidad de Extremadura 36 (2020): 863-896 ISSN: 0213-988X - ISSN-e: 2695-7728

Doi: https://doi.org/10.17398/2695-7728.36.863

\title{
LA REGULACIÓN DEL MATRIMONIO Y LOS BIENES GANANCIALES POR LA NORMATIVA HISTÓRICA ESPAÑOLA (SS. XVI-XIX)
}

\author{
THE REGULATION OF MARRIAGE AND COMMUNITY PROPERTY \\ BY SPANISH HISTORICAL LAWS (16TH-19TH CENTURIES)
}

\author{
RAQUel TOVAR PULIDo \\ Universidad de Extremadura
}

Recibido: 21/05/2020 Aceptado: 29/10/2020

\section{RESUMEN}

Abordamos la evolución de la legislación histórica relativa al matrimonio y a los bienes gananciales de la sociedad conyugal. Para ello, las fuentes histórico-jurídicas que se han empleado en este estudio son las leyes que los diferentes reyes de la Monarquía Hispánica promulgaron entre los siglos XVI-XIX. Concretamente, se ha procedido al análisis de la Novísima Recopilación de 1805. Se trata de una rica base documental que nos permite mostrar una visión de los esponsales en varias vertientes: por un lado, se profundiza en los requisitos que los novios debían cumplir para contraer matrimonio, así como en las prohibiciones y en la clandestinidad; por otro lado, se ofrece una aproximación a la administración y al reparto de los bienes conyugales, tanto los dotales como los gananciales.

Palabras clave: : Ordenamiento de Alcalá. Ordenamiento de Montalvo. Leyes de Toro. Novísima Recopilación de 1805. Consentimiento paterno. Patrimonio conyugal. Monarquía Hispánica. Antiguo Régimen 


\section{ABSTRACT}

It is studied the evolution of historical legislation, relating to marriage and community property in the conjugal society. For this question, it has been used the historicallegal sources as well as the laws that were promulgated between the 16th-19th centuries, by different kings of the Hispanic Monarchy. Specifically, it has been proceeded to the analysis of the Newest Compilation of 1805 . It is a complete documentary base that allows us to analysed the betrothal in two aspects: on the one hand, it delves into the requirements that the bride and groom needed to marriage, as well as in prohibitions on clandestine marriage; on the other hand, it offers an approach to the administration and distribution of marital property, both endowment and community property.

Keywords: Ordinance of Alcalá. Ordinance of Montalvo. Laws of Toro. Newest Compilation of 1805. Parental consent. Marital estate. Hispanic Monarchy. Old Regime.

Sumario: Introducción. 1. La regulación de la nupcialidad. 1.1. Prohibiciones y clandestinidad. 1.2. Los requisitos para contraer matrimonio: el consentimiento paterno. 2. El patrimonio conyugal. 2.1. La dote o donación propter nuptias y las arras. 2.2. La gestión de los bienes gananciales. 2.3. El reparto de gananciales para el cónyuge supérstite: viudedad y segundas nupcias. Conclusiones.

\section{INTRODUCCIÓN}

La década de los años setenta del siglo XIX, como consecuencia de las ideas liberales que se extendieron desde la Revolución Gloriosa de 1868 y provocaron el exilio de Isabel II, se caracteriza por una gran intensidad legislativa en la que hubo varios intentos de dar forma al matrimonio civil, que resultaba una novedad, dentro del tradicional e histórico sistema matrimonial canónico, que había sido regulado por la Iglesia durante siglos. La Constitución de 1869 establecía la aconfesionalidad del Estado y la libertad de culto e, inicialmente, el matrimonio civil se implantó en España a través de la Ley Provisional de 18 de junio de 1870, que fue promulgada por el Ministro de Gracia y Justicia, D. Eugenio Montero 
Ríosํ. Se pretendía que fuera el único sistema matrimonial reconocido en España, si bien mantenía el carácter perpetuo e indisoluble de la unión que había caracterizado al sistema matrimonial canónico. El matrimonio se concibe, así pues, como un contrato civil, a través del cual los esposos o contrayentes pasaban a formar parte de una sociedad vitalicia. El principio de perpetuidad e indisolubilidad del contrato matrimonial se explicaba por "la necesidad que tiene toda ley de ser garante del bien común” y rechazaba en su art. 1 el divorcio. No obstante, admitía la separación de hecho, pero sin que llegara a desaparecer el vínculo conyugal. Pero la honda tradición católica de los españoles no hizo desaparecer los matrimonios canónicos y, cinco años después, Antonio Cánovas del Castillo firmó el Decreto de 9 de febrero de 1875, que en el ámbito del nuevo sistema matrimonial otorgaba efectos retroactivos a los matrimonios canónicos que hubieran sido celebrados desde la Ley de 1870, así como establecía que el matrimonio civil quedaba reservado a aquellos que se declararan no católicos².

Con tales antecedentes, unos años más tarde y de manera definitiva, el matrimonio civil fue recogido, en 1889, en el Código Civil español3. Para la redacción de este cuerpo legal se tuvo como referente la Ley de Bases, de 11 de mayo de 1888, que dedicaba su base 3a. a la cuestión matrimonial4. No obstante, no

1 Esta ley, promulgada por el profesor de Derecho Canónico E. Montero Ríos, era provisional y mantenía la histórica indisolubilidad del matrimonio canónico, a partir de entonces conviviría con el matrimonio civil. Vid. Luis Ignacio Arechederra Aranzadi, "El matrimonio informal. (Nadie puede querer, lo que realmente quiere, sin quererlo)", Revista chilena de derecho 21, no 2 (1994): 227. https://dialnet.unirioja.es/servlet/articulo?codigo $=2649868$

2 Conforme a la Ley de Registro Civil de 17 de julio de 1870, en su reglamento de 13 de diciembre del mismo año, se daban instrucciones para que los contrayentes dieran la correspondiente información sobre identidad y residencia al Juez Municipal (art. 37). Actuaciones que anteriormente se venían haciendo en el ámbito eclesiástico. Sin embargo, en la práctica esto no se llevó a cabo por la población española, en su mayoría católica. La cual continuó contrayendo matrimonio canónico y no civil, así como ni siquiera cumplían con su obligación de inscribir en el Registro Civil los nacimientos y matrimonios, sino que lo hacían únicamente en los registros parroquiales, junto con las defunciones. Ello contrariaba la Real Orden de 11 de enero de 1872, que obligaba a inscribir en el Registro Civil a todos los hijos, incluso a los nacidos de matrimonio canónico. Esta fue derogada por el Decreto de 22 de enero de 1875, que recuperaba la importancia del matrimonio canónico. A partir de entonces únicamente podían inscribirse como legítimos los hijos que fueran fruto de matrimonios canónicos y, por tanto, no de los civiles. Vid. Demetrio Fernández Ucelay, "La evolución histórica de las formas de extinción del vínculo matrimonial”, Revista de Jurisprudencia. Lefebvre. El derecho 1 (2018) (en línea) https://elderecho.com/la-evolucion-historica-de-las-formas-de-extincion-del-vinculo-matrimonial

3 Vid. Arechederra, "El matrimonio informal...", 4.

4 Ley de Bases de 1888 y Real Decreto de 24 de julio 1889 -EDL 1889/1-. 
implicaba la desaparición del matrimonio canónico, pues el art. 42 del CC establecía el reconocimiento por la ley de ambas formas matrimoniales: por un lado, aquellos que profesaran la religión católica debían obligatoriamente contraer matrimonio canónico. Lógicamente este produciría todos los efectos civiles respecto a los cónyuges, sus bienes y los hijos que nacieran del matrimonio. Para lo cual se exigía la asistencia a la celebración del Juez Municipal u otro funcionario del Estado, para verificar la inscripción del enlace en el Registro Civil. Por otro lado, el matrimonio civil quedaba reservado a los no católicos o a quienes desearan casarse por lo civil y declararan no pertenecer a la Religión católica5.

La Constitución republicana de 1931 contemplaba el principio de aconfesionalidad del Estado, ante lo cual se promulgó la Ley del 28 de junio de 1932, mediante la cual se implantó el matrimonio civil obligatorio en España. Se derogó así el art. 42 del CC y, además, la indisolubilidad del matrimonio desaparece también, pues meses antes se había aprobado el divorcio en la Ley de 2 de marzo de 1932. Pero estas modificaciones en materia civil no duraron mucho, pues al finalizar la guerra civil española (1936-1939), el régimen franquista estableció un estado confesional. Se aprobó la Ley de 12 de marzo de 1938, que a su vez derogó la Ley de 28 de junio de 1932 y, con ello, el matrimonio civil obligatorio, que no desapareció del todo pero su presencia sería muy reducida. Asimismo, la Orden de 22 de marzo de 1938 recuperó la exigencia de que uno de los cónyuges declarase que no profesaba la religión católica, para poder casarse por lo civil, aunque esto se produjo en raras ocasiones. Posteriormente, la Orden de 22 de abril de 1939 ordenaba inscribir como válidos los matrimonios canónicos celebrados durante la República, cuando solo se celebraban legalmente los civiles. Meses después, la Ley de 23 de septiembre de 1939 derogó el divorcio civil, así como declaró la nulidad de las sentencias firmes de divorcio vincular respecto a los matrimonios canónicos. Además, procedió a la disolución de las uniones

5 En la II República se volvió al sistema de matrimonio civil facultativo, por lo que la Orden de 10 de febrero de 1932 dispuso que no se exigiera a los contrayentes ninguna declaración sobre sus creencias religiosas. 
civiles de aquellos que, en un anterior matrimonio, hubieran estado casados mediante el rito canónico con otra persona ${ }^{6}$.

Así pues, el matrimonio canónico continuó siendo obligatorio a finales de la centuria del siglo XIX y también durante el siglo XX, hasta la Constitución de 1978, salvo en los años de la I y II República, en los cuales únicamente regía el régimen de matrimonio civil7.

En lo que concierne a la historiografía sobre la historia del matrimonio, el estudio de la nupcialidad en España ha sido abordado por distintos expertos en el ámbito nacional e internacional que, desde las últimas décadas del siglo XX hasta nuestros días, han ampliado el marco teórico que gira en torno a las relaciones conyugales. Las interpretaciones que han destacado la importancia de la institución del matrimonio durante el Antiguo Régimen son de gran interés para los estudios sobre la Historia de la Familia española y han puesto su atención en los contratos matrimoniales, las estrategias familiares y los valores y la moralidad impuesta entre los casados ${ }^{8}$. No obstante, la normativa histórica relativa a este tema, que es de gran trascendencia para el Derecho Histórico de familia, es

6 Sobre esta cuestión en: Vid. Fernández, "La evolución histórica...”.

7 A partir de la Constitución de 1978 España vuelve a ser un Estado aconfesional, así como se declara la libertad de culto y la libertad ideológica. Vid. Título I. De los derechos y deberes fundamentales. Capítulo segundo. Derechos y libertades. Sección $1^{a}$ De los derechos fundamentales y de las libertades públicas (Art. 16) "Se garantiza la libertad ideológica, religiosa y de culto de los individuos y las comunidades sin más limitación, en sus manifestaciones, que la necesaria para el mantenimiento del orden público protegido por la ley". "Nadie podrá ser obligado a declarar sobre su ideología, religión o creencias". "Ninguna confesión tendrá carácter estatal. Los poderes públicos tendrán en cuenta las creencias religiosas de la sociedad española y mantendrán las consiguientes relaciones de cooperación con la Iglesia Católica y las demás confesiones".

8 Cabe mencionar algunos de los trabajos de importancia sobre esta materia: en lo relativo al derecho histórico en torno al matrimonio canónico Vid. Jean Gaudemet, El matrimonio en Occidente (Madrid: Taurus, 1993); sobre la idea de autoridad familiar y la moral en el s. XVIII Vid. Antonio Arbiol, $L a$ familia regulada (Zaragoza: Institución "Fernando el Católico", 200o). Otros estudios sobre nupcialidad en el ámbito internacional y en España en: Ignacio Arellano y Jesús María Usunáriz, eds., El matrimonio en Europa y el mundo hispánico. Siglos XVI y XVII (Madrid: Visor, 2005); María José de la Pascua, "Una aproximación a la historia de la familia como espacio de afectos y desafectos: el mundo hispánico en el setecientos”, Chronica Nova 27 (2000): 131-166 https://dialnet.unirioja.es/servlet/articulo?codigo=67713; Mónica Bolufer Peruga, Amor, matrimonio y familia: la construcción histórica de la familia moderna (Madrid: Síntesis, 1998); - "Las ambigüedades del sentimiento: el amor conyugal en textos del XVIII”, en Pablo Fernández Albaladejo y Margarita Ortega López, eds., Antiguo Régimen y Liberalismo. Homenaje a Miguel Artola, T. 3 (Madrid: Alianza Editorial, Ediciones de la Universidad Autónoma de Madrid, 1995), 429-438; María Victoria López-Cordón y Montserrat Carbonell, eds., Historia de la mujer e historia del matrimonio (Murcia: Universidad de Murcia, 1997). 
muy heterogénea y ha ido evolucionando con el paso del tiempo; por lo que ofrecemos un análisis del matrimonio a partir del estudio de la legislación histórica que gira en torno a esta compleja cuestión. Así pues, ponemos en valor las distintas normas matrimoniales comprendidas entre los siglos XVI y XIX.

Concretamente se ha procedido al análisis de la Novísima Recopilación de las leyes de España, que fue publicada a través de una Real Cédula el 15 de julio del año 1805, durante el reinado del monarca D. Carlos IV de Borbón. Supone la creación de un cuerpo legal que reúne en 12 libros el derecho castellano de los siglos anteriores. Contempla parte de las leyes procedentes de dos ordenamientos medievales: el Ordenamiento de Alcalá (1348) y el Ordenamiento de Montalvo de (1484); y de los dos grandes cuerpos legales del siglo XVI: las Leyes de Toro (1505) y la Recopilación de Leyes de estos reinos o Nueva Recopilación de Leyes de Castilla (1567), y sus posteriores ratificaciones y modificaciones que fueron realizadas por los monarcas sucesivos, durante los siglos XVII y XVIII9.

El nuevo cuerpo legal de 1805, además de una refundición de las leyes ya existentes, supuso también la actualización de la legislación española ${ }^{10}$. Se mantuvo vigente durante prácticamente toda la centuria del ochocientos, hasta que en 1889 fue aprobado el Código Civil. Concretamente para este estudio hemos abordado el análisis del Libro X, que consta de 24 Títulos y está dedicado al Derecho Civil, se titula De los contratos y obligaciones, testamentos y herencias. A su vez, los títulos que han sido analizados son los siguientes: Título II. De los esponsales y matrimonios; y sus dispensas; Título III. De las arras y dotes; y el

9 Las labores de creación de la Nueva Recopilación de Castilla se remontan a 1534, pero fue promulgada el 14 de marzo de 1567 por el rey Felipe II, para su aplicación en los territorios de Derecho Común de la Corona de Castilla, ya que los territorios forales, el reino de Navarra y la Corona de Aragón tenían su propia legislación. El proyecto fue iniciado por el jurista Pedro López de Alcocer, así como participaron también en su elaboración López de Arrieta o Bartolomé de Atienza, el Consejo Real y la Chancillería de Valladolid.

10 El encargado de su elaboración y del suplemento fue Juan de la Reguera Valdelomar, relator de la Chancillería de Granada. Los 12 libros contienen 4.044 leyes sistematizadas en un total de 340 títulos. El Derecho político y Administrativo se recoge en los libros del 1 al 9; el Derecho Civil se recoge en el décimo; mientras que los dos últimos están dedicados al Derecho Procesal y al Derecho Penal. 
Título IV. De los bienes gananciales o adquiridos en el matrimonio, cuyo contenido se desglosa en los apartados siguientes ${ }^{11}$.

Se trata de una rica base documental que nos permite mostrar una visión de los esponsales en varias vertientes: por un lado, se profundiza en los requisitos que los novios debían cumplir para contraer matrimonio, así como en las prohibiciones y la clandestinidad; por otro lado, se ofrece una aproximación a la administración y al reparto de los bienes conyugales, tanto los dotales como los gananciales, una vez disuelto el matrimonio y, por tanto, la sociedad conyugal.

\section{LA REGULACIÓN DE LA NUPCIALIDAD}

El mercado matrimonial históricamente ha estado condicionado por diferentes factores que influían en la elección de esposo o esposa. Por un lado, los limitados márgenes de movilidad geográfica de la época hacían que el Antiguo Régimen se caracterizara por una nupcialidad en la que predominaba la endogamia geográfica, pues los cónyuges procedían de la misma localidad o de otras localidades próximas y pertenecientes a la misma comunidad rural de origen, el concejo o la comarca ${ }^{12}$. Por tanto, las migraciones como consecuencia de la nupcialidad han sido contempladas generalmente a corta y media distancia ${ }^{13}$. Por

11 Novísima Recopilación, Libro X. De los contratos y obligaciones, testamentos y herencias (Madrid, 1805). Biblioteca Jurídica Digital, acceso en noviembre de 2020, https://www.boe.es/ biblioteca_juridica/publicacion.php?id=PUB-LH-1993-63\&tipo $=$ L\&modo $=2$

$12 \mathrm{Al}$ reducido mercado matrimonial de las zonas rurales ponían más obstáculos los impedimentos surgidos de la cognatio spirituales, impedimento de parentesco espiritual o entre padrinos. Carmen Pérez-Coca Sánchez-Matas, "El sacramento del matrimonio en el sínodo placentino de 1534", Anuario de la Facultad de Derecho de la Universidad de Extremadura 2 (1983): 373-376.

https://dialnet.unirioja.es/servlet/articulo?codigo $=813988$

13 En Castilla, los estudios sobre nupcialidad en Ávila han demostrado que en los siglos XVII y XVIII la nupcialidad era fundamentalmente endogámica y, en algunas ocasiones, hacía necesaria la solicitud de dispensas de consanguinidad. Raquel Tovar Pulido, "Casarse entre primos: matrimonios de conveniencia y consanguinidad en la España rural durante la época moderna (ss. XVII-XVIII)", Revista de Historia Social y de las Mentalidades 2 (2019): 215-247 (Ejemplar dedicado a: Migrations: Theory and History) DOI: https://doi.org/10.35588/rhsm.v23i2.3590; - "Las repercusiones de la Guerra de Sucesión Española en la segundo nupcialidad y la movilidad geográfica: Ávila Meridional", en José Pablo Blanco Carrasco, coord., Las segundas nupcias en la Edad Moderna: Una mirada a los límites del mercado matrimonial en España y Portugal (Madrid: Sílex, 2020), 157-191.

Ello se ve reflejado del mismo modo en Extremadura, en zonas rurales de Cáceres entre el siglo XVIII y XIX: Vid. Raquel Tovar Pulido, "Población y estructura matrimonial en el territorio del Partido de Navalmoral a finales del Antiguo Régimen y segunda mitad del siglo XIX (1787-1887)", en Domingo 
otro lado, a estos condicionamientos se sumaban las circunstancias económicas, el mantenimiento del estatus y de la posición social entre las familias más poderosas, pero también la supervivencia de aquellas más humildes, para las que la dote, como adelanto de la legítima paterna, suponía un elemento imprescindible para concertar matrimonio. A todas estas limitaciones era preciso añadir las obligaciones ya impuestas por la legislación canónica de la época, tales como el consentimiento paterno y el cumplimiento de las directrices observadas por la doctrina de la Iglesia católica ${ }^{14}$.

\subsection{PROHIBICIONES Y CLANDESTINIDAD}

Hasta la segunda mitad del siglo XVI, junto al matrimonio in facie ecclesiae, que era celebrado en una Iglesia mediante el rito católico, también eran considerados válidos los enlaces matrimoniales a yuras. Estos últimos consistían en el simple juramento de los cónyuges, por lo que se celebraban al margen de cualquier formalidad eclesiástica ni publicidad pero, a pesar de ello, disfrutaban de

Quijada González, coord., XXI Coloquios Histórico-Culturales del Campo Arañuelo. Dedicados a D. Ângel Sánchez Pascual, poeta, ganador del Premio Adonais en 1975 (Cáceres: Ayuntamiento de Navalmoral de la Mata, 2015), 181-201.

También en Portugal, los registros parroquiales del concejo de Marvão ponen en evidencia que los novios se casaban con naturales de las aldeas del mismo concejo o de aquellos con los que hacían frontera. La movilidad a media y larga distancia también se da, pero es menos frecuente y tiene como protagonistas principalmente a hombres solteros, incide menos en la segundo nupcialidad, así como la movilidad entre mujeres solteras y viudas es muy pequeña comparada con la de los hombres. Sobre esta cuestión Vid. Raquel Tovar Pulido, "Nubentes e mobilidade geográfica em Portugal no século XIX (1800-1830): o concelho de Marvão", Revista da Faculdade de Letras. Historia 9, nº 1 (2019): 148176. DOI: 10.21747/0871164X/hist9_1a7

14 A los novios no les estaba permitida la convivencia antes del matrimonio, si bien las relaciones extraconyugales eran frecuentes y, como consecuencia de ello, las demandas de cumplimiento de promesa de matrimonio ante tribunales civiles y eclesiásticos, pues estas eran causa de fuero mixto, pero las relativas a la interrupción o anulación del enlace no contaban con competencia civil. En lo que a ello respecta, eran las mujeres las que salían mal paradas, tras haber perdido la virginidad y, con ello, la deshonra de ellas y de la familia. Esta discriminación al sexo femenino también se producía entre los casados cuando se producía una infidelidad, pues esta actuación por parte de las esposas era rechazada por completo, mientras que para los hombres infieles no pasaba de una mera reprobación, cuando no indiferencia por parte de la sociedad o incluso se llegaba a comprender su comportamiento. Vid. Alonso Manuel Macías Domínguez y María Luisa Candau Chacón, "Matrimonios y conflictos: abandono, divorcio y nulidad eclesiástica en la Andalucía moderna (Arzobispado de Sevilla, siglo XVIII)", Revista complutense de historia de América 42 (2016): 120 y 134 (Ejemplar dedicado a: Dossier: Matrimonio en los siglos XVI-XVIII: derecho canónico, conflictos y realidad social) DOI: http://dx.doi.org/ 10.5209/RCHA.53713 
similares efectos que los primeros "en cuanto a perpetuidad, fidelidad, filiación y derechos inter vivos o mortis causa"15. Tales matrimonios consensuales eran muy comunes y ello comenzó a generar preocupación entre las altas jerarquías eclesiásticas, puesto que no se podía asegurar la legitimidad jurídica de matrimonios en los que el único testimonio que constaba era la voluntad y palabra de los contrayentes, quienes incluso podían llegar a contraer matrimonio en más de una ocasión, con otras personas, sin que existiera un control de tales actos.

El Concilio de Trento (1545-1563) supuso un antes y un después en la regulación del matrimonio, porque estableció nuevas normas y una mayor rigidez en la regulación de los esponsales ${ }^{16}$. Frente a la cierta relajación eclesiástica y civil que se había vivido en el período medieval, desde la segunda mitad del siglo XVI quedaron prohibidos los matrimonios clandestinos y se implantó la obligatoriedad de que los casamientos entre los bautizados se llevaran a cabo por un párroco y ante la presencia de dos testigos, pues de lo contrario carecerían de validez. Asimismo, era necesario el consentimiento paterno, así como se procedería al registro parroquial del enlace en el correspondiente libro de casados o de matrimonios.

Tales directrices fueron fijadas a través del Decreto Tametsi, que fue aprobado el 11 de noviembre de 1563, en la sesión XXIV del Concilio de Trento ${ }^{17}$. Se entiende a partir de ahora que el matrimonio no concierne únicamente a quienes lo contraen, sino que es un acto de unión que ha de ser aprobado socialmente y ha de contar con el consentimiento de la Iglesia ${ }^{18}$. Este decreto canónico papal llegó a España un año después, cuando el 12 de junio de 1564 fue instaurado por Felipe II, máximo defensor del catolicismo en la Monarquía Hispánica, a través

15 De manera paulatina comenzaron a establecerse sanciones a este tipo de matrimonios clandestinos, con el objetivo de acabar con esta práctica. Fernández, "La evolución histórica...”.

16 Hubert Jedin, Historia del Concilio de Trento (Pamplona: Universidad de Navarra, 1975), 99 y ss.; Sara Acuña-Guirola, "La forma del matrimonio hasta el Decreto Ne Temere", Ius Canonicum XIII, n. 25 (1973): 137 y ss. https://dialnet.unirioja.es/servlet/articulo?codigo=4607442; Aquilino José Iglesia Ferreiros, "Uniones matrimoniales y afines en el Derecho Histórico español", Revista de Derecho Notarial 85-86 (1974): 71-107.

17 Decreto Tametsi, Doctrina et canones de sacramento matrimonii. Punto 1797. El matrimonio es indisoluble. Canones super reformatione circa matrimonium. Decret. Tametsi. Punto 1813. Cap. 1. No matrimonio clandestino. 1563. En total constaba de diez capítulos.

18 Arechederra, "El matrimonio informal...", 3 . 
de una Real Cédula en las Cortes de Madrid ${ }^{19}$. No obstante, la desobediencia a la normativa conciliar era castigada con la pérdida de todos los bienes para los contrayentes de matrimonios clandestinos y la desheredación paterna, así como también para los testigos, a favor de la Cámara y Fisco. Además, todos serían desterrados de los reinos, sin posibilidad de retorno y bajo pena de muerte ${ }^{20}$. Desde entonces su aplicación se prolongó durante el Antiguo Régimen y se vio continuada en el periodo constitucional, hasta principios del siglo XX, cuando fue publicado el Código de Derecho Canónico, en el año $1917^{21}$.

1.2. LOS REQUISITOS PARA CONTRAER MATRIMONIO: EL CONSENTIMIENTO PATERNO

El Sacramento del Matrimonio debía realizarse con la libre voluntad de los cónyuges. Se trataba de uno de los requisitos esenciales que debía ser tenido en cuenta en el periodo moderno, se contempla en la normativa del siglo XVII y tenía precedentes en la legislación medieval. Pues ya en el siglo XIV diferentes peticiones reales establecían la prohibición de que las mujeres solteras o viudas fueran obligadas a casarse con un hombre en contra de su voluntad 22 .

19 Cap. 58. Vid. Novísima Recopilación, Libro X. De los contratos y obligaciones, testamentos y herencias. Titulo II. De los esponsales y matrimonios; y sus dispensas. Ley V. Prohibición de matrimonios clandestinos; y pena de los que los contraxeren, é intervinieren en ellos (Madrid, 1805).

20 "Mandamos, que el que contraxere matrimonio, que la Iglesia tuviere por clandestino, con alguna muger, que por el mismo fecho él y los que en ello intervinieren, y los que del tal matrimonio fueren testigos, incurran en perdimiento de todos sus bienes, y sean aplicados á nuestra Cámara y Fisco; y sean desterrados de estos nuestros reynos, en los quales no entren, só pena de muerte; y que esta sea justa causa para que el padre y la madre puedan desheredar, si quisieren, á sus hijos ó hijas, que el tal matrimonio contraxeren; en lo qual otro ninguno no pueda acusar sino el padre, y la madre, muerto el padre (ley I, tit. I; lib. 5 R.)". Ley 49 de Toro, en 1505 y la citada Real Cédula de Felipe II, 1564.

21 Tal y como indicaba Carmen Pérez Coca, para sus estudios sobre Plasencia en el s. XVI, cuando se había contraído anteriormente matrimonio clandestino, aunque uno de los cónyuges o ambos celebraron uno posterior dentro de los márgenes de la legalidad, si el primero fuera declarado válido, el segundo se invalidaría. Este tipo de matrimonios implicaban la ilegitimidad también de los hijos que fueran fruto de estos enlaces. Vid. Pérez-Coca, "El sacramento del matrimonio...”, 11.

22 "Si acaeciere que por importunidad nos mandaremos dar alguna. carta ó mandamiento, para que alguna doncella o viuda, ó otra qualquier haya de casar con alguno contra su voluntad, y sin su consentimiento, mandamos, que la tal carta no vala; y el que por ella fuere emplazado, que no sea tenudo de parecer ante nos; y por no parescer no incurra en pena alguna (ley 10. tit. 1. lib. 5. R.)". Vid. Novísima Recopilación, Libro X. De los contratos y obligaciones, testamentos y herencias. Titulo II. De los esponsales y matrimonios; $y$ sus dispensas. Ley II. Nulidad de las Reales cartas ó mandamientos para 
Las causas que llevaban a la Iglesia a considerar un matrimonio inválido ya han sido mencionadas en el apartado anterior, si bien los mayores problemas que se van a dar entre los jóvenes que deseaban unirse en matrimonio van a estar relacionados con las circunstancias familiares y, concretamente, con la falta de consentimiento paterno ${ }^{23}$. En este sentido, la normativa era muy clara al respecto y en el siglo XVIII se aprobaron, por parte de la Monarquía Borbónica, varias pragmáticas que pretendían regular el consentimiento de los padres para que los hijos de familia contrajeran matrimonio. En 1776, Carlos III exponía la gran preocupación que había por la celebración de matrimonios desiguales entre los hijos de las familias de las clases altas sin el consentimiento paterno, debido a que no existían penas civiles que castigaran a los contraventores. Así pues, estableció la obligatoriedad, para los hijos e hijas menores de 25 años, de contar con el consentimiento del padre o, en su ausencia, de la madre viuda y, en su defecto, de los abuelos por línea paterna y materna; pero si todos hubieran fallecido, se pediría permiso a los dos parientes mayores de edad más cercanos, en defecto de los cuales serían los tutores y curadores quienes se encargarían de dar su aprobación para la celebración del contrato matrimonial ${ }^{24}$. No obstante,

que muger alguna case contra su voluntad. D. Alonso en Alcalá pet. 31 año 1348; D. Enrique II. en Burgos año 1373 pet. 4; y D. Juan I. allí año 1379 pet. 9.

23 Sobre conflictos entre padres e hijos por desobediencia, a través de expedientes judiciales Vid. José Pablo Blanco Carrasco, "Notas sobre la desobediencia intergeneracional durante los últimos compases de la España Moderna", Tiempos modernos: Revista Electrónica de Historia Moderna 9, $\mathrm{n}^{\circ} 38$ (2019): 323-344. https://dialnet.unirioja.es/servlet/articulo?codigo=7004493

24 “(...) por no hallarse respectivamente declaradas las penas civiles en que incurren los contraventores , mandé examinar esta materia en una Junta de Ministros, con encargo de que dexando ilesa la autoridad Eclesiástica y disposiciones canónicas en quanto al Sacramento del Matrimonio para su valor, subsistencia y efectos espirituales, me propusiese el remedio mas conveniente, justo , y conforme á mi autoridad Real en órden al contrato civil, y efectos temporales; cuyo dictámen remití al Consejo pleno quien me expuso su parecer : conformándome con él, he tenido bien expedir esta mi carta, y pragmática-sancion en fuerza de ley, que quiero tenga el mismo vigor, que si fuese promulgada en Cortes , por la qual, y para la arreglada observancia de las leyes del Reyno, desde las del Fuero Juzgo que hablan en punto á los matrimonios de los hijos é hijas de familia menores de veinte y cinco años, mando, que estos deban, para celebrar el contrato de esponsales, pedir y obtener el consejo y consentimiento de su padre, y en su defecto de la madre, y á falta de ambos, de los abuelos por ambas líneas respectivamente, y no teniéndolos, de los dos parientes mas cercanos que so hallen en la mayor edad, y no sean interesados ó aspirantes al tal matrimonio, y no habiéndolos capaces de darle, de los tutores ó curadores; bien entendido, que prestando los expresados parientes, tutores, ó curadores su consentimiento, deberán executarlo con aprobacion del Juez Real, é interviniendo su autoridad, sino fuese interesado; y siéndolo, se devolverá esta autoridad al Corregidor ó Alcalde mayor Realengo mas cercano". Vid. Libro X. De los contratos.... op. cit. Título II. De los esponsales...op. cit. Ley IX. Consentimiento paterno para la contracción de esponsales y matrimonio por los hijos de familia. Pragmática aprobada por D. Carlos III el 23 de marzo de 1776 y publicada el 27 del mismo. 
la aprobación por parte de la familia no quedaba reservada únicamente a las clases distinguidas, sino que también se veía extendida para las familias más humildes 5 .

En los siguientes puntos de la misma pragmática, se contemplaban las penas que se impondrían a aquellos que contravinieren la voluntad de los padres, los cuales junto a sus descendientes perderían todos sus derechos civiles, relativos a la dote y la legítima paterna, a suceder como herederos forzosos en los bienes libres y demás herencia de padres y abuelos. De modo que quedaban completamente desheredados y únicamente conservaban el derecho de alimentos ${ }^{26}$. Igualmente, perderían sus derechos sobre vínculos, patronatos y otros derechos perpetuos, ya que serían postergados en el orden de llamamientos y, en caso de ser el último descendiente, la sucesión pasaba a los transversales, hasta la extinción de las líneas descendientes del fundador de los vínculos o mayorazgos ${ }^{27}$.

El respeto a la autoridad paterna y a la familia era tal que también se aconsejaba a los hijos mayores de 25 años que pidieran consejo a los padres para concertar matrimonio, pues en caso contrario se les aplicarían las mismas

25 “(...) porque en todas sin diferencia tiene lugar la indispensable y natural obligacion del respeto á los padres, y mayores que esten en su lugar, por Derecho natural y divino, y por la gravedad de la eleccion de estado con persona conveniente, cuyo discernimiento no puede fiarse á los hijos de familia y menores, sin que intervenga. la deliberacion y consentimiento paterno, para reflexionar las conseqüencias, y atajar con tiempo las resultas turbativas y perjudiciales al público y á las familias". Vid. Libro X. De los contratos... Titulo II. De los esponsales... Ley IX. Consentimiento paterno para la contraccion de esponsales y matrimonio por los hijos de familia. Pragmática aprobada por D. Carlos III el de 23 de Marzo de 1776 y publicada en 27 del mismo.

26 “(...) quedarán inhábiles, y privados de todos los efectos civiles, como son el derecho á pedir dote ó legítimas , y de suceder como herederos forzosos y necesarios en los bienes libres , que pudieran corresponderles por herencia de sus padres ó abuelos , á cuyo respeto y obediencia faltaron contra lo dispuesto en esta pragmática; declarando como declaro por justa causa de su desheredacion la expresada contravencion ó ingratitud, para que no puedan pedir en juicio, ni alegar de inoficioso ó nulo el testamento de sus padres ó ascendientes; quedando estos en libre arbitrio y facultad de disponer de dichos bienes á su voluntad, y sin mas obligacion que la de los precisos y correspondientes alimentos". Vid. Libro X. De los contratos... Titulo II. De los esponsales... Ley IX. Consentimiento paterno para la contraccion de esponsales y matrimonio por los hijos de familia. Pragmática aprobada por D. Carlos III el de 23 de Marzo de 1776 y publicada en 27 del mismo.

27 “(...) y así ellos como sus descendientes sean y se entiendan postergados en el orden de los llamamientos, de modo que pasando al siguiente en grado, en quien no se verifique igual contravencion, no puedan suceder hasta la extincion de las lineas de los descendientes del fundador, ó personas en cuya cabeza se instituyeron los vínculos ó mayorazgos". Vid. Libro X. De los contratos.... Titulo II. De los esponsales.... Ley IX. Consentimiento paterno para la contraccion de esponsales y matrimonio por los hijos de familia. Pragmática aprobada por D. Carlos III el de 23 de Marzo de 1776 y publicada en 27 del mismo. 
imposiciones que a los menores de edad ${ }^{28}$. Sin embargo, la legislación no daba la razón en todos los casos a los padres, sino que también contemplaba la posibilidad de escuchar la opinión de los hijos, por lo que la misma pragmática establecía que los padres no debían obligar a los hijos a casarse en contra de su voluntad con personas que no eran de su agrado. Se trataba de una costumbre habitual por cuestiones de intereses familiares y entre las clases altas, donde no eran extraños los matrimonios de conveniencia ${ }^{29}$. Ello iba en contra de la libertad de los contrayentes, que debían reservarse un afecto y amor recíproco para la celebración del Santo Sacramento. De modo que se declaró la conveniencia de que la familia prestara su consentimiento a los hijos y que, en caso contrario, fuera muy bien justificada la causa de la negativa, por ejemplo, por ir en contra del honor de la familia o porque perjudicara al Estado, pero no por capricho de los padres, abuelos, parientes, curadores o tutores ${ }^{30}$. Por ello y porque no eran poco frecuentes estos casos de irracional disenso de los padres, existía la posibilidad de que los hijos, emitieran un recurso sumario a la Justicia Real Ordinaria en contra de la decisión tomada por su familia y que ellos consideraban injusta. El plazo de resolución era breve, de apenas ocho días, porque el objetivo era

28 "Los mayores de veinte y cinco años cumplen con pedir el consejo paterno para colocarse en estado de matrimonio, que en aquella edad ya no admite dilacion, como está prevenido en otras leyes; pero si contravinieren, dexando de pedir este consejo paterno, incurrirán en las mismas penas que quedan establecidas, así en quanto á los bienes libres como en los vinculados". Vid. Libro X. De los contratos... Titulo II. De los esponsales... Ley IX. Consentimiento paterno para la contracción de esponsales y matrimonio por los hijos de familia. Pragmática aprobada por D. Carlos III el de 23 de Marzo de 1776 y publicada en 27 del mismo.

29 “(...) es justo precaver al mismo tiempo el abuso y exceso en que puedan incúrrir los padres y parientes, en agravio y perjuicio del arbitrio y libertad que tienen los hijos para la eleccion del estado á que su vocacion los llama, y en caso del de matrimonio, para que no se les obligue ni precise á casarse con persona determinada contra su voluntad; pues .ha manifestado la experiencia, que $\cdot$ muchas veces los padres y parientes por fines particulares é intereses privados intentan impedir que los hijos se casen, y los destinan á otro estado contra su voluntad y vocacion, ó se resisten á consentir en el matrimonio justo y honesto , que desean contraer sus hijos, queriéndolos casar violentamente con persona á que tienen repugnancia, atendiendo regularmente mas á las conveniencias temporales, que á los altos fines para que fué instituido el santo Sacramento del matrimonio". Vid. Libro X. De los contratos... Titulo II. De los esponsales... Ley IX. Consentimiento paterno para la contracción de esponsales y matrimonio por los hijos de familia. Pragmática aprobada por D. Carlos III el de 23 de Marzo de 1776 y publicada en 27 del mismo.

30 "“...) declaro y mando, que los padres, abuelos, deudos, tutores y curadores en su respectivo caso deban precisamente prestar su consentimiento, si no tuvieren justa y racional causa para negarlo, como lo seria, si el tal matrimonio ofendiese gravemente al honor de la familia, ó perjudicase al Estado". Vid. Libro X. De los contratos... Titulo II. De los esponsales... Ley IX. Consentimiento paterno para la contracción de esponsales y matrimonio por los hijos de familia. Pragmática aprobada por D. Carlos III el de 23 de Marzo de 1776 y publicada en 27 del mismo. 
agilizar lo máximo posible la celebración de los matrimonios de manera justa; mientras que cabía la posibilidad de presentar un recurso ante la Audiencia, Consejo o Chancillería de su territorio, que sería resuelto en un plazo de un mes ${ }^{31}$. Una vez emitida la resolución, era posible dar certificación del auto favorable o adverso, pero eran confidenciales las objeciones propuestas por cada una de las partes, pues se trataba de evitar difamaciones de personas y de las familias involucradas ${ }^{32}$.

Pese a las disposiciones promulgadas y a las instrucciones dadas a las familias y a los jóvenes, los garantes del cumplimiento de la normativa canónica eran los propios eclesiásticos, en tanto que encargados de celebrar el matrimonio y declarar a los novios marido y mujer. De ahí que, lógicamente, la pragmática que estamos analizando encargara el cuidado de este asunto a los ordinarios eclesiásticos, sus provisores y vicarios, quienes tendrían que impedir la admisión de esponsales y demandas de esponsales sin el debido consentimiento paterno o de la familia33. Justamente para asegurar el cumplimiento por parte de

31 "Y así contra el irracional disenso de los padres, abuelos, parientes, tutores ó curadores, en los casos y forma que queda explicada respecto á los menores de edad, y á los mayores de veinte y cinco años, debe haber y admitirse libremente recurso sumario á la Justicia Real ordinaria, el qual se haya de terminar y resolver en el preciso término de ocho dias , y por recurso, en el Consejo, Chancillería ó Audiencia del respectivo territorio en el perentorio de treinta dias; y de la declaracion que se hiciese, no haya revista, alzada ni otro recurso, por deberse finalizar con un solo auto, ora confirme ó revoque la providencia del inferior, á fin de que no se dilate la celebracion de los matrimonios racionales y justos”. Vid. Libro X. De los contratos..... Titulo II. De los esponsales.... Ley IX. Consentimiento paterno para la contracción de esponsales y matrimonio por los hijos de familia. Pragmática aprobada por D. Carlos III el de 23 de Marzo de 1776 y publicada en 27 del mismo.

32 “(...) y será puramente extrajudicial é informativo semejante proceso; y aunque se oiga á las partes en él por escrito o verbalmente, será siempre á puerta cerrada. Y declaro incursos en perpetua privación de oficio á los Jueces y Escribanos, que diesen ó mandasen dar copia simple ó certificada de los procesos, que se formaren sobre suplir el irracional disenso de los padres, deudos ó tutores, pues los tales procesos en qualquiera Juzgado que se terminaren, han de: quedar custodiados en el archivo secreto y separado, de modo que por ninguna persona puedan registrarse ni reconocerse, ni darse tampoco segunda certificación del auto sin expresa orden y mandato del mismo Consejo". Vid. Libro X. De los contratos.... Titulo II. De los esponsales.... Ley IX. Consentimiento paterno para la contracción de esponsales y matrimonio por los hijos de familia. Pragmática aprobada por D. Carlos III el de 23 de Marzo de 1776 y publicada en 27 del mismo.

33 “(...) que para evitar las referidas contravenciones, y penas en que incurrirán los hijos de familias, y no darles causa ni motivo para que falten á la obediencia debida a los padres, ni padezcan las tristes consecuencias que resultan de tales matrimonios, pongan en cumplimiento de la encíclica de Benedicto XIV. el mayor cuidado y vigilancia en la admision de esponsales y demandas, á que no preceda este consentimiento, ó de los que deban darle gradualmente, aunque vengan firmados ó escritos los tales contratos de esponsales de los que intentan solemnizarlos sin el referido asenso de los padres, ó de los que están en su lugar”. "Que para atajar estos matrimonios desiguales, y evitar los perjuicios del Estado 
los prelados, Carlos III había emitido una Real Cédula el 3 de marzo de 1776 dirigida a ellos 34 . Años después, en 1784, el mismo monarca emitió una cédula del Consejo en el que establecía que todas las diócesis de España debían practicar el método que había seguido en Cataluña el Arcipreste de Ager, para los matrimonios de los hijos de familia. Este seguía el catecismo de San Pio V y enseñaba a los fieles la obligación de la bendición de los padres para contraer matrimonio, ante lo cual tal aprobación se indicaba en la publicación de las moniciones y, después de haberse celebrado el enlace por palabras de presente, se hacía referencia a la aprobación paterna en la partida de matrimonio35. La obediencia

y familias, se observe inviolablemente por los Ordinarios eclesiásticos, sus Provisores y Vicarios lo dispuesto en el Concilio de Trento en punto á las proclamas, excusando su dispensacion voluntaria" "Para la observancia de todo lo referido, y en uso de la proteccion que la potestad Real debe dispensar al mas exacto cumplimiento de las reglas canónicas, al respeto de los hijos de familias á sus Padres y mayores, y al conveniente órden y tranquilidad de las familias, de que depende la del Estado en gran parte, ruego y encargo á los M. RR. Arzobispos, como Metropolitanos, á los RR. Obispos y demas prelados en sus diócesis y territorios, hagan que sus Provisores, Visitadores, Promotores Fiscales, Vicarios, Curas, Tenientes y Notarios se instruyan de esta mi pragmática, y de las prevenciones explicadas en ella, para que igualmente promuevan y concurran á su debida observancia y cumplimiento”. Vid. Libro X. De los contratos.... Titulo II. De los esponsales.... Ley IX. Consentimiento paterno para la contracción de esponsales y matrimonio por los hijos de familia. Pragmática aprobada por D. Carlos III el de 23 de Marzo de 1776 y publicada en 27 del mismo.

34 "Como la Iglesia siempre y en todos tiempos detestó, y prohibe los matrimonios que se celebran sin noticia, ó contra el justo y racional disenso de los padres, la Santidad de Benedicto XIV. en su enciclica de 17 de Noviembre de 1741 encarga, que cuidadosamente se. examine y averigüe la qualidad, grado, condicion y estado de las personas que solicitan contraerlos, y paticularmente si son hijos de familias , cuyos padres justamente disienten en la celebracion de semejantes matrimonios: y siendo muy propio del ministerio pastoral de los Prelados, y demas Jueces eclesiásticos evitar sériamente toda ocasion y motivo de que los hijos falten á la debida obediencia de sus padres, de que resultan tantas ofensas á Dios, y funestas consecuencias al honor y tranquilidad de las familias; he venido, en uso de la proteccion debida al santo Concilio de Trento, á la mas pura Disciplina eclesiástica, y á lo que en esta parte recomienda la Santidad del Papa Benedicto XIV., en dirigiros la pragmática, que he mandado expedir á consulta de mi Consejo pleno; y espero de vuestro zelo pastoral, que daréis las.mas oportunas providencias, para que tengan su debido efecto en la parte que os toca". Vid. Libro X. De los contratos... Titulo II. De los esponsales... Ley X. Se encarga á los Prelados el cumplimiento de lo dispuesto en la anterior pragmática. Aprobada por D. Cárlos III. por Real cédula de 3 de Marzo de 1776.

35 "(...) que era la moral que habia mandado se leyese, y practicase, se enseñaba públicamente á los fieles la doctrina siguiente. que faltan los hijos de familia, que sin el consejo y bendicion de sus padres tratan de contraer matrimonio; y que estando en pecado mortal no se les puede admitir á la participacion de los santos Sacramentos, y por ello se les deba dilatar hasta haber practicado esta diligencia; que quando se tenia noticia de que el hijo de familia pidió al padre, y obtuvo su consentimiento , en la publicacion de moniciones, que por ningun caso se dispensaba en los matrimonios de esta naturaleza, se expresaba la circunstancia de haberse tratado y convenido el matrimonio con expreso consentimiento de los padres, y en la partida que se escribía en los cinco libros, se añadia también esta circunstancia, despues de haberse celebrado con palabras de presente el matrimonio, siendo cargo de la visita de cinco libros la omision de ella, que se hacía rigurosamente todos los años contra los Curas Párrocos en el caso de haber sido omisos; y que quando acontecia disentir el padre de familias, se enviaba el conocimiento del disenso al Juez secular competente , y miéntras pendía y estaba indecisa la resolucion , se suspendia todo ulterior procedimiento, cuya práctica era la que el Arcipreste había mandado 
y el cumplimiento de tales exigencias eran obligatorias para los curas párrocos de cada territorio, pero también para los Tribunales y Justicias. En diciembre de 1784 y febrero de 1785 se promulgaron varias cédulas que ordenaban a estos la vigilancia de que los prelados diocesanos y territoriales hicieran cumplir la práctica del Arcipreste de Ager, así como se trataba de eliminar la costumbre relativa a las extracciones y depósitos voluntarios, ejecutados por los Jueces eclesiásticos, con respecto a las hijas de familia sin noticia, lo cual iba en contra de la voluntad de sus padres, parientes y tutores ${ }^{36}$.

Dichos depósitos de las hijas de familia o "secuestros" eran el resultado de los disentimientos o desacuerdos entre ellas y sus padres. Era decretado por un Juez eclesiástico, para reducir a matrimonio los esponsales que había contraído la hija, tras el disenso o la negativa de la madre y cuando dicha falta de consentimiento estaba en manos de la Justicia Real; si bien este depósito debía ser realizado siendo conocedor el eclesiástico de si estaba o no razonado dicho disenso37. En este sentido, en su último año de vida, en 1788, el monarca aprobó

observar en cumplimiento de la Real pragmática; y lo hacia presente al Consejo, para que viese si habia alguna cosa que añadir para la perfecta observancia de la ley Real, de cuyo interes por el bien temporal y espiritual estaba tan persuadido; y que todo lo obedecería puntualmente como buen ciudadano y vasallo mio. Y habiéndose visto en el mi Consejo lo que exponía el Arcipreste de Ager, mando, se le respondiese, que quedaba enterado y aprobaba la práctica que se observaba en aquel Arciprestazgo, la que extendiese, é hiciese saber á todos los Curas Párrocos para el mismo fin; y que si para ello contemplase conveniente fixar edicto, lo hiciese (...)". Vid. Libro X. De los contratos.... Titulo II. De los esponsales.... Ley XIV. En todas las diócesis se practique el método del Arcipreste de Ager en quanto á matrimonios de los hijos de familia. Aprobado por Carlos III por resol. á cons. de 13 de Marzo, y céd, del Consejo de 17 de Junio de 1784 .

36 "Los Tribunales y Justicias del reyno .cumplan exactamente con lo resuelto en la anterior cédula de 17 de Junio de 1784, cuidando de su puntual execucion y cumplimiento , y dando cuenta al mi Consejo de la menor contravencion que observen, sin permitir que con pretexto alguno se falte á las formalidades que se refieren en la práctica establecida por el Arcipreste de Ager, adoptada uniformemente por todos los Prelados diocesanos y territoriales de estos mis reynos; y en su conseqüencia no consientan las extracciones y depósitos voluntarios, que han solido executar los Jueces eclesiásticos, de las hijas de familia sin noticia v contra la voluntad de sus padres' parientes y tutores, segun sus respectivos casos; ni tampoco otro ningun procedimiento, haya tanto que en sus respectivas Curias se presenten las licencias y asensos pacerenos, ó la equivalente declaracion de irracional disenso por la Justicia Real, por ser tales procedimientos opuestos á tan justificada práctica y á las cédulas expedidas posteriormente, á cuyo fin darán los autos y providencias que convengan”. Vid. Libro X. De los contratos.... Titulo II. De los esponsales.... Ley XV. Cumplimiento de la antecedente cédula por los Tribunales y Justicias; y modo de executar los depósitos voluntarios de las hijas de familia. Aprobado por D. Carlos III por resolución a consejo de 22 de Diciembre de 1784, y cédula del Consejo de 1 de Febrero de 1785. 37 "Con motivo de haberse decretado por un Juez eclesiástico el depósito de una hija de familia, para reducir á matrimonio los esponsales que habia contraído despues de estar executoriado ante la Justicia Real el irracional disenso de su madre, se quejó esta de dicha providencia, y del depósito que en su 
nuevas cédulas en las que indicaba que sólo los hijos de familia podían pedir el consentimiento a sus padres u otros familiares, así como no se debían admitir en los Tribunales eclesiásticos demandas de esponsales celebrados sin el consentimiento paterno ${ }^{38}$.

Con el inicio del siglo XIX y ya con Carlos IV como rey, la nueva normativa borbónica cambió las directrices impuestas años atrás por su padre. En 1803 promulgó una pragmática por Real Decreto, en Aranjuez, mediante la cual redujo la minoría de edad de los jóvenes por la que estaban obligados a pedir consentimiento paterno cuando desearan contraer esponsales. Los hijos menores de 25 años y las hijas menores de 23 tenían que pedir permiso, pero el padre no estaba obligado a indicar una causa justificada en el caso de que su respuesta fuera negativa a la celebración matrimonial39. En este aspecto los hijos salían

virtud se hizo ; y he venido en declarar, que sus depositos por opresion, y para explorar la libertad se expidan por el Juez, que respectivamente deba conocer segun el recurso, pues si este fuere; sobre ser ó no racional el disenso, conocerá el Juez Real, y decretará quando sea necesario el depósito; y si fuere sobre esponsales, despues de evacuado el juicio instructivo sobre el disenso ante la Justicia secular, conocerá el Eclesiástico, impartiendo para la execucion el auxilio de brazo seglar; y he tenido á bien encargar al mi Consejo, que sobre las extracciones, y depósitos de las hijas de familia haga observar esta regla". Vid. Libro X. De los contratos.... Titulo II. De los esponsales.... Ley XVI. Depósitos judiciales de las hijas de familias para explorar su libertad. Aprobada por D. Carlos III. por Real orden de 30 de Septiembre, y céd. del Consejo de 3 de Octubre de 1785.

38 "Considerando el mi Consejo ser necesaria una literal y formal declaracion para evitar se exciten y promuevan dudas y disputas, embarazando con cavilaciones los Tribunales, y motivando recursos contrarios al espíritu de la misma Real pragmática , y cédulas de 17 de Junio de 1784 y 10 de Febrero de 785 ( leyes14 y 15) con grave perjuicio y muchos gastos de los interesados, trató y examinó del asunto con la detenida reflexion que exigia su importancia, y me hizo presente lo que estimó conveniente en consulta de 3 de Julio de este año; y por mi Real resolucion á ella, conformandome con su parecer, he venido en declarar y mandar por punto general, que solo los hijos de familia son los que puedan pedir el consentimiento á sus padres , abuelos, tutores, ó personas de quienes dependan para contraer matrimonio; y asimismo que no se deben admitir en los Tribunales eclesiásticos demandas de esponsales celebrados sin el consentimiento paterno contra lo mandado por mi Real Pragmática de 23 de marzo de 1776 (ley 9), y cédulas de 17 de junio de 1784 y de primero de febrero de 1785; no debiéndose admitir tampoco por vía de impedimento, careciendo de la principal circunstancia sin la que no pueden habilitarse para parecer en juicio por ninguno de los dos conceptos, pues en ambos casos se ha de hacer constar siempre, previamente y en debida forma, de los expresados consentimientos, o por su negación, del suplemento de la Justicia a quien corresponda, declarando por irracional el disenso". Vid. Libro X. De los contratos.... Titulo II. De los esponsales.... Ley XVII. Consentimiento que deben pedir los hijos de familia para sus esponsales y matrimonios. Aprobado por Carlos III por resolución á consulta de 3 de Julio, y céd. de 18 de Septiembre de 1788.

39 "Con presencia de las consultas que me han hecho mis Consejos de Castilla e Indias sobre la pragmática de matrimonios de 23 de marzo de 1776 (ley 9), órdenes y resoluciones posteriores, y varios informes que he tenido a bien tomar, mando, que ni los hijos de familia menores de 25 años, ni las hijas menores de 23, a cualquiera clase del Estado que pertenezcan, puedan contraer matrimonio sin licencia de su padre, quien, en caso de resistir el que sus hijos e hijas intentaren, no estará obligado a dar la razón, ni explicar la causa de su resistencia o disenso". Vid. Libro X. De los contratos.... Titulo II. De 
perjudicados aparentemente; no obstante, se estableció que aquellos que ya hubieran cumplido 25 años y aquellas que tuvieran al menos 23 años no necesitaban pedir permiso paterno; mientras que, ante la ausencia del padre, tampoco estarían obligados a pedir permiso si el varón había cumplido 24 y la mujer 23, de modo que se adelantaba en este caso la edad para ser libres de concertar matrimonio. Asimismo, ante la ausencia de ambos progenitores, los abuelos paterno y materno tenían la misma autoridad y se adelantaba nuevamente la edad para casarse, esta vez en dos años, a los 23 los varones y a los 21 años las mujeres. Del mismo modo, si tampoco vivieran los abuelos, eran los tutores los encargados de autorizar el casamiento y, en su defecto, el Juez del domicilio, y las edades disminuían a su vez a 22 años en los varones y 20 años en las mujeres.

En todos estos casos tampoco estaban obligados a justificar los motivos de rechazo del enlace. Pero los novios tenían la posibilidad de recurrir ante el rey para que, a la vista de los informes, diera la concesión o negativa definitiva del permiso o habilitación para la celebración del matrimonio. Una vez aclarada la cuestión de la edad y del representante legal de los futuros contrayentes, estos pedían licencia al rey, Cámara o Gobernador del Consejo ${ }^{40}$. Asimismo, esta libertad para los jóvenes se daba para todas las clases sociales, si bien quedaba restringida para los miembros de la Familia Real, quienes en ningún caso adquirirían la libertad para casarse a su arbitrio sin licencia del rey ${ }^{4}$.

los esponsales.... Ley XVIII. Nuevas reglas para la celebración de matrimonios, y formalidades de los esponsales para su validación. D. Carlos IV en Aranjuez por Real decreto de 10 de Abril de 1803, inserto en pragmática de 28.

40 "Para los matrimonios de las personas que deben pedirme licencia, o solicitarla de la Cámara, Gobernador del Consejo o sus respectivos Jefes, es necesario que los menores, según las edades señaladas, obtengan esta después de la de sus padres, abuelos o tutores, solicitándola con la expresión de la causa que estos han tenido para prestarla; y la misma licencia deberán obtener los que sean mayores de dichas edades, haciendo expresión, cuando la soliciten, de las circunstancias de la persona con quien intenten enlazarse. Aunque los padres, madres, abuelos y tutores no tengan que dar razón a los menores de las edades señaladas de las causas que hayan tenido para negarse a consentir en los matrimonios que intentasen, si fueren de la clase que deben solicitar mi Real permiso, podrán los interesados recurrir a mí, así como a la Cámara, Gobernador del Consejo o Jefes respectivos, los que tengan esta obligación, para que por medio de los informes que tuviere yo a bien tomar, o los dichos creyesen convenientes en sus casos, se conceda o niegue el permiso o habilitación correspondiente, para que estos matrimonios puedan tener o no efecto". Vid. Libro X. De los contratos.... Titulo II. De los esponsales.... Ley XVIII. Nuevas reglas para la celebración...op. cit.

41 "En las demás clases del Estado ha de haber el mismo recurso a los Presidentes de Chancillerías y Audiencias, y al Regente de la de Asturias, los cuales procederán en los mismos términos. Los vicarios 


\section{EL PATRIMONIO CONYUGAL}

El patrimonio conyugal y su administración entre los cónyuges tiene como antecedentes históricos su regulación en el periodo medieval, concretamente en el Fuero Real (1255) de Alfonso X de Castilla "El Sabio", donde se estipulaba un reparto igualitario para el hombre y para la mujer, de aquellos bienes que estos obtuvieran por compra u otros medios estando casados; salvo aquello que hubiera sido donado a uno solo, el cual sería el único propietario ${ }^{42}$. Asimismo, la herencia recibida por el marido sería para su persona, pero las ganancias que obtuviera por su trabajo en hueste sin soldada lo tenía que compartir con su mujer, como bienes comunes del matrimonio43. En lo que respecta a las propiedades que cada uno de los esposos hubiera aportado al matrimonio o heredado durante el mismo, todos los frutos que obtuvieran de su explotación debían ser repartidos entre ambos a partes iguales, independientemente de que uno tuviera mayor número de posesiones que el otro44. En este sentido, los estudios sobre

eclesiásticos que autorizaren matrimonio, para el que no estuvieren habilitados los contrayentes según los requisitos que van expresados, serán expatriados y ocupadas todas sus temporalidades, y en la misma pena de expatriación y en la de confiscación de bienes incurrirán los contrayentes. En ningún Tribunal eclesiástico ni secular de mis dominios se admitirán demandas de esponsales, sino es que sean celebrados por personas habilitadas para contraer por sí mismas según los expresados requisitos, y prometidos por escritura pública; y en este caso se procederá en ellas, no como asuntos criminales o mixtos, sino como puramente civiles. (...) Todos los matrimonios que a la publicación de esta mi Real determinación no estuvieren contraídos, se arreglarán a ella sin glosas, interpretaciones ni comentarios, y no a otra ley ni pragmática anterior (6, que se aplica de aquí en adelante, no en lo pendiente de dispensación o ya dispensado)". Vid. Libro X. De los contratos..... Titulo II. De los esponsales.... Ley XVIII. Nuevas reglas para la celebración...op. cit.

42 "Toda cosa que el marido y muger ganaren ó compraren, estando de consuno, háyanlo ambos por medio; y si fuere donadío de Rey ó de otro, y lo diese á ambos, háyanlo marido y muger; y si lo diere al uno, háyalo solo aquel á quien lo diere. (ley 2. tit. 9. lib. 5. R.)” Ley 1. tit. 3. lib. 3. del Fuero Real. Vid. Libro X. De los contratos.... Titulo IV. De los bienes gananciales, Ó adquiridos en el matrimonio. Ley I. Modo de partir entre marido y muger los bienes adquiridos en el matrimonio.

43 "Si el marido alguna cosa ganare de herencia de padre ó de madre, ó de otro propinquo, ó de donadío de señor, ó de pariente ó de amigo, ó en la hueste del Rey, ó de otro que vaya por su soldada, háyalo todo quanto ganare por suyo; y si fuere en hueste sin soldada, á costa de si y de su muger, quanto ganare desta guisa, todo sea del marido y de la muger, ca así como la costa es comunal de ambos, lo que así ganaren sea comunal de ambos, esto que dicho es de suso de las ganancias de los maridos, eso mismo sea de las mugeres. (ley 3. tit. 9. lib. 5. R.)". Ley 2. tit. 3. lib. 3. del Fuero Real. Vid. Libro X. De los contratos.... Titulo IV. De los bienes gananciales, Ó adquiridos en el matrimonio. Ley II. Bienes comunes á marido y muger Y los pertenecientes á cada uno por sí.

44 "Maguer que el marido haya mas que la muger, ó la muger mas que el marido, quier en heredad quier en mueble, los frutos sean comunes de ambos á dos; y la heredad, y las otras cosas do vienen los frutos, háyalas el marido ó la muger cuyas ántes eran , ó sus herederos (ley 4. tit. 9, lib. 5. R.)”. Ley 3. 
patrimonios familiares han puesto de manifiesto que, en el periodo moderno, el patrimonio conyugal, sobre todo en las zonas rurales, solía estar constituido por fincas rústicas, en los cuales los frutos se correspondían a la explotación agrícola-ganadera, al cultivo de cereales, frutales y huertas. En el mediodía peninsular predominaba la tríada mediterránea (olivo, viña y cereal) y la producción de aceite y vino, además de miel. En la explotación de cabañas ganaderas destacaba la ovina, bovina o porcina, mientras que se tenía ganado caballar para el trabajo en el campo. En lo que respecta al patrimonio inmueble urbano, en ocasiones las familias contaban con varias viviendas por cuyo alquiler recibían rentas anuales. Todos estos beneficios formarían parte, por tanto, del patrimonio conyugal 45 .

\subsection{LA DOTE O DONACIÓN PROPTER NUPTIAS Y LAS ARRAS}

Como paso previo al enlace y requisito para el contrato matrimonial se producía la redacción de la carta de dote, que consistía en el inventario de los bienes que se le adelantaban a la novia de la legítima paterna. Dicho inventario recogía detalladamente las características económicas del ajuar de boda con el cual los novios iniciaban la vida conyugal en un nuevo hogar, por lo que en el listado aparecía generalmente ropa de cama, muebles para la alcoba, menaje de cocina y ropa de uso diario, así como alguna joya u objetos de adorno personal, así como el precio o cantidad en la que estaba valorada cada pieza. Entre las familias más pudientes también figuraba algo de dinero y alguna propiedad inmueble.

tit. 3. lib. 3. del Fuero Real. Vid. Libro X. De los contratos.... Titulo IV. De los bienes gananciales, Ó adquiridos en el matrimonio. Ley III. Los frutos de los bienes propios del marido ó de la muger sean comunes.

45 Se desarrollan estas cuestiones, a través del estudio del patrimonio familiar gestionado por la mujer viuda, en los siguientes trabajos Vid. Raquel Tovar Pulido, "Mujeres en la jefatura del hogar, trabajo y riqueza patrimonial en Trujillo (Extremadura) en la segunda mitad del siglo XVIII", en Raquel Tovar Pulido, dir. De humilde e ilustre cuna: Retratos familiares de la España Moderna (siglos XV-XIX) (Évora: CIDEHUS-Universidad de Évora, 2020), 153-178; - "La riqueza patrimonial de las familias de las viudas jiennenses en el siglo XVIII", Cuadernos de historia moderna, Vol. 42, № 1 (2017): 195-220 DOI: https://doi.org/10.5209/CHMO.56660; -"Viudas hacendadas y labradoras: la propiedad femenina en el noreste andaluz a mediados del siglo XVIII (el Reino de Jaén)”, en María Ángeles Pérez Samper y José Luis Betrán Moya, coord., Nuevas perspectivas de investigación en Historia Moderna: economía, sociedad, política y cultura en el mundo hispánico, (Barcelona: Universidad de Barcelona y Universidad Autónoma de Barcelona, 2018), 317-331. 
Asimismo, las arras correspondían a los bienes o capital que el futuro esposo aportaba al matrimonio ${ }^{46}$.

La legislación medieval recogida en el Fuero Real establecía como cuantía máxima para las arras la décima parte de los bienes del varón, disposición que se recogía en la Ley 50 de Toro, del siglo XVI, y que se mantendrá durante todo el Antiguo Régimen 47. Tales bienes en el caso de las mujeres, como se ha indicado, pertenecían a los adelantos de las legítimas paternas en vida de los progenitores y, en el caso de los varones, a los bienes paternos también, así como a patrimonio personal que hubieran ganado con su trabajo, lo cual cuando se trataba de viudos podía alcanzar una gran cuantía. Normalmente el pago de la dote o donación propter nuptias procedía de los bienes comunes de los padres, pero si estos no fueran suficientes cabía la posibilidad de que incluyeran a medias otros bienes que poseyeran cada uno por separado48. Sin embargo, podía suceder que los padres hubieran fallecido en un momento anterior al matrimonio, de modo que las jóvenes también tenían que llevar dote y arras al matrimonio, pero la cantidad estipulada sería la que hubieran convenido los padres antes de

46 Raquel Tovar Pulido, "Cultura material de la élite local española del siglo XVIII a través de la dote de doña Ana María Orozco y Venegas (Linares)”, en Diana Arauz Mercado, coord., Investigaciones sobre Humanidades y Artes, Colección Pasado, Presente y Porvenir. Vol. VIII (Zacatecas, México: Zezem Baltza Editores, 2020), 249-268.

47 "La ley del Fuero, que dispone que no pueda el marido dar mas en arras á su muger de la décima parte de sus bienes, no se, pueda renunciar; y si se renunciare, no embargante la tal renunciacion, lo contenido en la dicha ley se guarde y execute: y si algun Escribano diere fe de algun contrato, en que intervenga renunciacion de la dicha ley, mandamos que incurra en perdimiento del oficio de Escribanía que tuviere, y de allí en adelante no pueda usar mas de él, so pena de falsario" (ley 2. tít. 2. lib. 5. R.) Ley 50 de Toro. Vid. Libro X. De los contratos.... Título III. De las arras y dotes. Ley I. No se pueda renunciar la ley del Fuero prohibitiva de dar en arras mas de la décima parte de los bienes del marido. 48 "Si el marido y la muger, durante el matrimonio , casaren algun hijo comun, y ámbos le prometieron la dote ó donacion propter nuptias, que ambos la paguen de los bienes que tuvieren ganados durante el matrimonio ; y si no los hubiere que basten la paga de la dicha dote y donacion prapter nuptias, que lo paguen de por medio de los otros bienes que les pertenescieren en qualquier manera ; pero si el padre solo durante el matrimonio dota, ó hace donacion propter nuptias á algun hijo comun , y de tal matrimonio hubiere bienes de ganancia, de aquello se pague en lo que en las ganancias cupiere; y si no las hubiere, que la tal dote ó donacion propter nuptias se pague de los bienes del marido, y no de la muger. (ley 8. tit. 9. lib. 5. R.)". Ley 53 de Toro. Vid. Libro X. De los contratos.... Titulo III. De las arras y dotes. Ley IV. Modo de pagar la dote ó donacion própter nuptias prometida al hijo por marido y muger durante el matrimonio. 
morir o la correspondiente a los bienes heredados por vía testamentaria por los hijos 49 .

Asimismo, en lo que concierne a las cantidades estipuladas para dar en dote a las hijas, también existían unos límites, al igual que sucedía con las arras, como ya se ha mencionado. El motivo es que, con frecuencia, sucedía que los padres se endeudaban para poder casar a sus hijas y ello ocasionó en numerosas ocasiones una ruina para la familia. Por ello, las sucesivas leyes de 1534, 1573 y 1623 que aprobaron los Austrias regulaban esta cuestión en función de la riqueza de la familia. Así pues, quienes tuvieran una riqueza menor a 200.000 maravedís de renta no podían dar más de 600.00o; así, la persona que tuviere entre 200.000 maravedís y 500.000 maravedís de renta podía ofrecer una dote para cada una de sus hijas de hasta un cuento de maravedís; mientras que quien tuviera una riqueza anual de más de 500 maravedís podía dar un cuento y medio de dote. Por su parte, quien tuviera un cuento y medio de renta podría dar la renta de un año a cada hija, sin exceder de doce cuentos. Además, ningún padre podía dar el tercio ni quinto de los bienes para la boda de la hija ${ }^{50}$. El

49 "Quando algun hijo ó hija viniere á heredar ó partir los bienes de su padre ó .de su madre ó de sus ascendientes, sean obligados ellos y sus herederos á traer á colacion y particion la dote y donacion propter nuptias, y las otras donaciones que hubiere rescebido de aquel cuyos bienes vienen á heredar : pero si se quisieren apartar de la herencia, que lo puedan hacer; salvo si la tal dote ó donaciones fueren inoficiosas, que en este caso mandamos, que sean obligados los que las rescibieren, ansi los hijos y descendientes en lo que toca á las donaciones, como las hijas y sus maridos en lo que toca á las dotes, puesto que sea durante el matrimonio, á tornar á los otros herederos del testador aquello en que son inoficiosas, para que lo partan entre sí: y para se decir la tal dote inoficiosa se mire á lo que excede de su legítima, y tercio y quinto de mejoría, en caso que el que la dio podía hacer dicha mejoría, quando hizo la dicha donacion ó dió la dicha dote, habiendo consideracion al valor de los bienes del que dio o prometió la dicha dote, al tiempo que la dicha dote fue constituida o mandada, o al tiempo de la muerte del que dio la dicha dote o la prometió, do mas quisiere escoger aquel a quien fue la dicha dote prometida o mandada, pero las otras donaciones que se hicieren a los hijos, mandamos, que para ser decir inoficiosas, se haya consideración a lo que los dichos bienes del donador valieren al tiempo de su muerte (ley 3. Tit. 8. Lib. 5. R)”. Ley 29 de Toro. Vid. Libro X. De los contratos.... Titulo III. De las arras y dotes. Ley V. Obligación de los hijos á traer á colacion y particion las dotes y donaciones que hubieren recibido de sus difuntos padres; y declaracion de las inoficiosas.

50 La legislación castellana dividía el patrimonio de la persona en cinco partes. De las cuatro partes primeras, dos tercios eran obligatoriamente destinados a las legítimas que le pertenecían por derecho a los hijos, mientras que el tercio restante podía ser reservado a la mejora y que el padre o la madre lo destinara como quisiera para uno de los hijos. El quinto de los bienes correspondía a aquello que quedaba para libre disposición del testador y, generalmente, solía destinarse al entierro y a las misas. Se analiza esta cuestión en Raquel Tovar Pulido, "Escrituras testamentarias: la transmisión de bienes en la España Moderna", en XII Congreso de la Asociación de Demografía Histórica, (Universidad de Oporto. Del 4 al 7 de septiembre de 2019) (en prensa). 
incumplimiento de la normativa conllevaría la pérdida de los bienes indicados. Estas leyes que son promulgadas en el siglo XVI y ratificadas en el siglo XVII nuevamente, aunque con añadidos, contemplaban también la prohibición al futuro esposo de dar a las novias más de la octava parte de la dote en joyas y vestidos51. En el siglo XVIII, en 1723, D. Felipe V52 ratificó las leyes precedentes, que habían sido aprobadas por sus antepasados por línea paterna, y ordenó que los gastos del matrimonio no superaran la octava parte del montante de la dote de la novia53.

51 "Atenta la desórden y daños que somos informados, que se han recrecido y recrecen las dotes excesivas que se prometen, habemos mandado á los del nuestro Consejo, que viesen y platicasen sobre ello , y asimismo lo comunicasen con nuestras Audiencias, y con los Procuradores de Córtes, y otras personas de experiencia. $\mathrm{Y}$ habiendo visto los pareceres y acuerdos que sobre ello ha habido, mandamos, que de aquí adelante, en el dar y prometer de las dichas dotes, se tenga y guarde la manera y órden siguiente : -que qualquier caballero ó persona que tuviere 200 mil maravedís , y dende arriba hasta 500 mil maravedís de renta , pueda dar en dote á cada una- de sus hijas legítimas hasta un cuento de maravedís y no mas; y que el que tuviere ménos de los dichos 200 mil maravedís de renta, no pueda dar ni dé en dote arriba de 600 mil maravedís; y que. el que pasare de los dichos 500 mil maravedís hasta un .cuento y 400 mil maravedis de renta. pueda dar hasta un cuento y medio de maravedís; y que el que tuviere cuento y medio de renta y dende arriba, pueda dar en dote á cada una de las hijas legítimas que tuviere la rema de un año y no mas, con que no pueda exceder de doce cuentos de maravedís, no embargante que la dicha su renta de un año sea mas de los dichos doce cuentos en qualquiera cantidad: y mandamos, que ninguno pueda dar ni prometer, por via de dote ni casamiento de hija, tercio ni quinto de sus bienes, ni se entienda ser mejorada tácita ni expresamente por ninguna manera de contrato entre vivos (...)" (ley r. tit. .2. lib. 5. R.). Vid. Libro X. De los contratos.... Titulo III. De las arras y dotes. Ley VI. Cantidad que se puede dar en dote, y por el esposo á la esposa en joyas y vestidos. D. Carlos y D. Juana en Madrid año 1534 y D. Felipe II en las Córtes de Madrid año 1573 pet. 37; Vid. Ley VII. Observancia de la ley anterior, moderando las dotes y arras con varias declaraciones. D. Felipe IV. en Madrid por pragmática de 11 de Febrero de 1623.

52 Felipe V en la Ley VIII, arriba indicada, hace referencia a que Felipe IV era su bisabuelo. Aunque se produce ciertamente ante su llegada un cambio de dinastía, pues los Borbones suceden a Carlos II y ponen fin a la dinastía de los Hagsburgo en España, Felipe V era hijo de Luis de Francia, quien a su vez era hijo de María Teresa de Austria (su abuela), una de las hijas de Felipe IV, por tanto, su bisabuelo.

53 "Atento á que por el señor Rey Don Felipe IV, mi bisabuelo, en la ley precedente, se dio regla precisa en los gastos de los casamientos , mando, que de aquí adelante se guarde, cumpla y execute la dicha ley en todo y por todo como en ella se contiene, sin contravenirse : y asimismo mando, que precisamente todos los gastos que se hicieren, de qualquiera calidad que sean, con el motivo de bodas, se deban comprehender y comprehendan, sin exceder en manera alguna, en la octava parte de las dotes que se constituye en al tiempo de los matrimonios, segun las reglas prescriptas por las dos precedentes leyes. (cap. 25 del aut. 4. tit. 12. lib. 7. R.), Vid. Libro X. De los contratos.... Titulo III. De las arras y dotes. Ley VIII. Observancia de la ley precedente, con declaración de que los gastos hechos con motivo de las bodas se comprehendan en la 8. parte de las dotes constituidas al tiempo de los matrimonios. D. Felipe V. en San Ildefonso por pragmática de 5 de Noviembre de 1723 cap. 25. 


\subsection{LA GESTIÓN DE LOS BIENES GANANCIALES}

En los albores de la edad moderna, en 1473, todavía durante el reinado de Enrique IV, el hermano de la que más tarde le sucedería como la reina Isabel I de Castilla, "la Católica" 54 , se confirmaron las leyes establecidas previamente por el Fuero Real, mediante las cuales aquellos bienes que eran obtenidos por uno de los cónyuges mediante herencia o donación eran de su única propiedad, junto con los bienes castrenses del esposo por el desempeño de servicio militar; mientras que compartirían los frutos de los bienes de ambos y las rentas obtenidas por el desempeño de oficios. No obstante, cuando los bienes obtenidos durante el matrimonio por el esposo no fueran de origen castrense, este sí podía enajenarlos sin el permiso de su mujer, siempre que la intención del marido no fuera perjudicarla55.

El siglo XVI fue inaugurado en el campo del Derecho por las Leyes de Toro, en 1505, que fueron promulgadas en nombre de la reina Juana I de Castilla. En ellas se contemplaban los medios de acción que debían de tomarse en el caso de que uno de los cónyuges hubiera cometido un delito y cuáles eran las repercusiones para el otro esposo, en lo que al patrimonio conyugal se refiere. La Ley 77 de Toro establecía que, aunque se tratara incluso de delito de herejía, no debía perder sus bienes el esposo que no hubiera cometido tal delito, así como

54 En 1469 esta había contraído matrimonio con Fernando I de Aragón, fue coronada reina de Castilla el 13 de diciembre de 1474, tras la muerte de su hermano el 11 de diciembre, aunque la Guerra de Sucesión castellana contra los partidarios de Juana la Beltraneja se prolongó desde 1475 hasta 1479, resultando Isabel vencedora.

55 "Declarando las leyes del Fuero, y lo contenido en el Libro del Estilo de Corte, y las otras leyes que disponen sobre la manera que se ha de tener en los bienes ganados entre el marido y la muger durante el matrimonio, mando y ordeno, que todos y qualesquier bienes castrenses, y oficios de Rey, y donadíos de los que fueron ganados, y mejorados y habidos durante el matrimonio entre el marido y muger por el uno dellos, que sean y finquen de aquel que los hubo ganado, sin que el otro haya parte dellos, segun lo quieren las dichas leyes del Fuero; pero que los frutos y rentas dellos, y de todos otros qualesquier oficios, aunque sean de los que el Derecho hubo por casi castrenses, y los otros bienes que fueron ganados ó mejorados durante el matrimonio, y los frutos y rentas de los tales bienes castrenses y oficios y donadíos, que ambos los hayan de consuno. Y otrosi, que los bienes que fueren ganados, mejorados y multiplicados durante el matrimonio entre el marido y la muger, que no fueren castrenses ni casi castrenses, que los pueda enagenar el marido durante el matrimonio, si quisiere, sin licencia ni otorgamiento de su muger, y que el contrato de enagenamiento vala, salvo si fuere probado que se hizo cautelosamente por (defraudar ó damnificar á la mujer)”. (ley 5. tit. 9. lib. 5. R.)”. D. Enrique IV en Nieva año de 1473 pet. 12. Vid. Libro X. De los contratos..... Titulo IV. De los bienes gananciales, Ó adquiridos en el matrimonio. Ley V. Bienes comunes, y los pertenecientes á marido y muger, en declaracion de las precedentes leyes del Fuero y Estilo. 
tampoco la mitad correspondiente a los bienes gananciales que hubieran sido obtenidos durante el matrimonio ${ }^{6}$. No obstante, una vez que hubiera sido declarada la sentencia, la Ley 78 ordenaba que cuando la mujer casada había cometido un delito, podía perder los bienes dotales y también parte de sus gananciales, lo cual lógicamente implicaba una pérdida de bienes también para el esposo57.

Años más tarde, Felipe II, en 1566, aprueba nuevas leyes en las que mantiene como bienes comunes todos aquellos que tengan el marido y la mujer, salvo que uno de ellos probara la pertenencia exclusiva de parte de ellos ${ }^{8}$. Esta forma de reparto conyugal se va a mantener en los siglos siguientes en España, si bien existe una excepción, pues en Córdoba las mujeres casadas no tenían permitido participar en los gananciales que habían sido adquiridos durante el matrimonio. Esta ley desigual entre los sexos y discriminatoria para los derechos de las mujeres fue derogada entre 1801-1802 por Carlos III59. Asimismo, en

56 "Por el delito que el marido ó la muger cometiere, aunque sea de heregía, ó de otra qualquier qualidad, no pierda el uno por el delito del otro sus bienes, ni la mitad de las ganancias habidas durante el matrimonio: y mandamos, que sean habidos por bienes de ganancia todo lo multiplicado durante el matrimonio, hasta que por el tal delito los bienes de qualquier dellos sean declarados por sentencia, aunque el delito sea de tal calidad que imponga la pena ipso jure. (ley 10.tit. 9. lib. 5. R)”. Ley 77 de Toro. Vid. Libro X. De los contratos.... Titulo IV. De los bienes gananciales, Ó adquiridos en el matrimonio. Ley X. Ninguno de los conyuges, por delito del otro, pierda los bienes multiplicados hasta la sentencia declaratoria.

57 "La muger, durante el matrimonio, por delito pueda perder en parte ó en todo sus bienes dotales ó de ganancia, ó de otra qualquier qualidad que sean (ley r 1. tit. 9. lib. 5. R.)”. Ley 78 de Toro. Vid. Libro $X$. De los contratos.... Titulo IV. De los bienes gananciales, Ó adquiridos en el matrimonio. Ley XI. La muger casada pueda perder por delito los gananciales, y demas bienes que la pertenezcan.

58 "Como quier que el Derecho diga, que todas las cosas que han marido y muger, que todas se presumen ser del marido, hasta que la muger muestre que son suyas; pero la costumbre guardada es en contrario, que los bienes que han marido y muger, que son de ambos por medio, salvo los que probare cada uno que son suyos apartadamente; y ansi mandamos, que se guarde por ley. (ley 1. tit.9. lib. 5. R.)". Ley 203. del Estilo; y D. Felipe II año de 1566. Vid. Libro X. De los contratos.... Titulo IV. De los bienes gananciales, Ó adquiridos en el matrimonio. Ley IV. Los bienes que tengan el marido y muger se presuman comunes, no probando su respectiva pertenencia.

59 "Abolimos en quanto sea necesario la supuesta ley, costumbre ó estilo que ha gobernado hasta ahora en la ciudad de Córdoba, de que las mugeres casadas no tengan parte en los bienes gananciales adquiridos durante el matrimonio. En su consequencia queremos y mandamos, que la ley general de la participacion de las ganancias en los matrimonios sea extensiva á las mujeres Cordobesas de todo aquel reyno, segun y como se practica con las de Castilla y Leon. Y en esta conformidad mandamos al Corregidor de la expresada ciudad de Córdoba, á los Alcaldes mayores de ella , y demas á quienes corresponda, observen, guarden y cumplan la citada resolucion de nuestra Real Persona, haciéndola observar, guardar y cumplir en todo y por todo, segun y como en ella se contiene : yá fin de que esta Real resolucion tenga puntual observancia en todo el reyno, se comunique á las Chancillerías, Audiencias, Corregidores y Justicias de él”. Vid. Libro X. De los contratos.... Titulo IV. De los bienes gananciales, Ó 
algunos municipios de Extremadura existe una forma particular de reparto de los bienes gananciales, que fue reconocida en el Fuero de Baylío en la edad media y que reconoce como gananciales los bienes multiplicados durante el matrimonio, pero también aquellos que fueron aportados por cada uno de los miembros de la pareja conyugal. Dicho Fuero fue ratificado en 1778 por Carlos III60.

2.3. EL REPARTO DE GANANCIALES PARA EL CÓNYUGE SUPÉRSTITE: VIUDEDAD Y SEGUNDAS NUPCIAS

La legislación sobre la viudedad que se ofrece en la normativa analizada se remonta al periodo bajo medieval, cuando Enrique III, en 1400 y 1401, ordenó que las mujeres viudas pudieran contraer segundas nupcias en el transcurso de un año desde el fallecimiento del primer esposo. Para ello, anuló las leyes de Fueros y Ordenamientos anteriores que iban en contra de lo que esta nueva ley establecía. En el periodo precedente, la mujer no podía casarse hasta que hubiera transcurrido un año completo desde la muerte del esposo. El motivo era poder garantizar la paternidad de los hijos que nacieran del segundo matrimonio, ya que podía ocurrir que la viuda se hubiera quedado embarazada antes del fallecimiento del esposo e hiciera pasar a este hijo como legítimo del segundo

adquiridos en el matrimonio. Ley XIII. "Derogacion de la ley o costumbre, prohibitiva de que las mugeres Cordobesas participen de los gananciales adquiridos durante el matrimonio". D. Carlos IV. por resol. á cons. de 17 de Abril, y provis. de 16 de Junio de 1801 para Córdoba, y circ. del Consejo de 6 de Marzo de 1802.

6o "Apruebo la observancia del fuero denominado del Baylío, concedido á la villa de Alburquerque por Alfonso Tellez, su fundador, yerno de Sancho II, Rey de Portugal, conforme al qual todos los bienes que los casados llevan al matrimonio, ó adquieren por qualquiera razon, se comunican y sujetan á particion como gananciales: y mando, que todos los Tribunales de estos mis reynos se arreglen á él para la decision de los pleytos que sobre particiones ocurran en la citada villa de Alburquerque, ciudad de Xerez de los Caballeros, y demás pueblos donde se ha observado hasta ahora; entendiéndose sin perjuicio de providenciar en adelante otra cosa, si la necesidad o transcurso del tiempo acreditase ser más conveniente que lo que hoy se observa en razón del citado fuero, si lo representasen los pueblos". Vid. Libro X. De los contratos.... Titulo IV. De los bienes gananciales, Ó adquiridos en el matrimonio. Ley XII. Observancia del fuero del Baylío, en quanto á sujetar á particion, como gananciales, los bienes llevados o adquiridos en el matrimonio. D. Carlos III. por resol. á cons. de 15 de Sept., y céd. del Consejo de 20 de Dic. de 1778. 
matrimonio, si se casaba poco después de la muerte del primero y cuando aún no se le notaba que estaba en estado ${ }^{61}$.

En lo que respecta al patrimonio conyugal, en la misma centuria, pero ya en el reinado de Enrique IV, en 1473, la legislación establecía que la viuda debía vivir honradamente, pues de lo contrario se le impondría como pena la pérdida de su mitad de los bienes gananciales, en beneficio de la familia y de los herederos de su difunto esposo ${ }^{62}$. Posteriormente, la Ley 14 de Toro, en 1505, contemplaba la posibilidad de que el cónyuge supérstite dispusiera de los bienes gananciales del primer matrimonio, aunque hubiera contraído segundas o terceras nupcias ${ }^{63}$. No obstante, la Ley 15 ordenó que obligatoriamente la mujer tenía que reservar para los hijos de su esposo difunto la propiedad o usufructo de los bienes paternos ${ }^{64}$. Pero si no habían tenido descendencia y moría primero la

61 "Mandamos, que las mugeres viudas puedan libremente casar, dentro en el año que sus ·maridos murieren, con quien quisieren, sin alguna pena y sin alguna infamia ella ni el que con ella casare, no obstantes qualesquier leyes de Fueros y Ordenamientos, y otras qualesquier leyes que en contrario sean fechas y ordenadas, las quales anulamos y revocamos; y mandamos á los nuestros Jueces y Alcaldes de la nuestra Casa y Corte ; y Chancillería , y de todas las ciudades, y villas y lugares de nuestros reynos y señoríos, que no atienten de proceder, ni procedan por la dicha causa y razón contra las dichas viudas , ni contra aquellos que con ellas se casaren, so pena de dos mil maravedís para la nuestra Cámara; y los que lo contrario hicieren, sean emplazados, que parezcan ante nos en la nuestra Corte. (ley 3. tit. I, lib. 5. R.)". Vid. Libro X. De los contratos.... Titulo II. De los esponsales...op .cit. Ley IV. Las viudas puedan casar dentro del año en que mueran sus maridos. D. Enrique III en Cantalapiedra y Valladolid año 1400, y en Segovia año 1401.

62 "Y otrosí mando y ordeno, que si la muger fincare viuda, y siendo viuda, viviere luxuriosamente, que pierda los bienes que hubo por razon de su mitad de los bienes que fueron ganados y mejorados por su marido y por ella , durante el matrimonio entre ellos , y sean vueltos los tales bienes á los herederos de su marido difunto en cuya compañía fueron ganados (ley 5. tit..9. lib. 5. R.)”. D. Enrique IV en Nieva año de 1473 pet. 12. Vid. Libro X. De los contratos.... Titulo IV. De los bienes gananciales, Ó adquiridos en el matrimonio. Ley V. Bienes comunes, y los pertenecientes á marido y muger, en declaracion de las precedentes leyes del Fuero y Estilo.

63 "Mandamos, que el marido y la muger, suelto el matrimonio, aunque casen segunda ó tercera vez ó mas, puedan disponer libremente de los bienes multiplicados durante el primero, ó segundo ó tercero matrimonio, aunque haya habido hijos de los tales matrimonios , ó de alguno dellos, durante los quales matrimonios los dichos bienes se multiplicaron, como de los otros sus bienes propios que no hubiesen sido de ganancia, sin ser obligados á reservar á los tales hijos propiedad ni usufructo de los tales bienes (ley 6. tit. .9. lib. 5. R.)". Ley 14 de Toro. Vid. Libro X. De los contratos.... Titulo IV. De los bienes gananciales, Ó adquiridos en el matrimonio. Ley VI. Facultad del conyuge que superviva, para disponer de los bienes multiplicados en el matrimonio, sin obligacion á reservarlos para los hijos de él.

64 "En todos los casos que las mugeres, casando segunda vez, son obligadas á reservar á los hijos del primer matrimonio la propiedad de lo que hubieren del primer marido, ó heredaren de los hijos del primer matrimonio , en los mismos casos el varon que casare segunda ó tercera vez, sea obligado á reservar la propiedad de ello á los hijos del primer matrimonio; de manera que lo establecido cerca deste caso en las mugeres que casaren segunda vez, haya lugar en los varones que pasaren á segundo ó tercero matrimonio (ley 4.tit.I. lib. 5. R.)" Ley 15 de Toro. Vid. Libro X. De los contratos.... Titulo IV. 
mujer, las arras del marido pasarían a los herederos de esta y no al esposo viudo $^{65}$. En el caso de que muriera primero el hombre, la Ley 54 establecía que si el matrimonio no había sido consumado el total de los bienes recaería en los herederos del esposo y la mujer perdería la mitad que le correspondía por ley. En caso contrario, cuando tuvieran descendencia, ella y sus hijos tendrían derecho a todos los bienes que este les hubiera dejado66. Asimismo, aquellos bienes que el cónyuge supérstite recibiera del difunto por vía testamentaria, a modo de manda, se contarían de manera separada de su mitad correspondiente a los bienes gananciales ${ }^{67}$. Sin embargo, al igual que se heredaban los bienes, los viudos también heredaban las deudas contraídas durante el matrimonio. Por este motivo, la legislación también ofrecía la posibilidad para las mujeres de renunciar a los gananciales, para no ser obligada a pagar las deudas que el marido hubiere contraído en vida, tal y como se regula en la Ley 60 de Toro ${ }^{68}$.

De los bienes gananciales, Ó adquiridos en el matrimonio. Ley VII. Casos en que los padres que pasan á segundo matrimonio, deben reservar á los hijos del primero la propiedad de los bienes del difunto. 65 "Si la muger no hubiere fijo del matrimonio en que interviniere promision de arras, sino dispone expresamente de las dichas arras, que las haya el heredero ó herederos de ella, y no el marido, ora la muger faga testamento ó no" (ley 3. tit. .2. lib. S. R.) Ley 51 de Toro. Vid. Libro X. De los contratos.... Titulo III. De las arras y dotes. Ley II. Los herederos de la muger hayan las arras, y no el marido, en defecto de hijos.

66 "Qualquier esposa, ora sea de presente, ora sea de futuro, suelto el matrimonio, gane ( si el esposo la hobiere besado ) la mitad de todo lo que el esposo la hobiere dado ántes de consumado el matrimonio, ora sea precioso ó no; y si no la hubiere besado, no gane nada de lo que la hobiere dado, y tornese á los herederos del esposo; pero si qualquier de ellos muriere despues de consumado el matrimonio , que la muger y sus herederos ganen todo lo que, seyendo desposados, la hobo el esposo dado, no habiendo arras en el tal casamiento y matrimonio ; pero si arras hobiere que sea en escogimiento de la muger ,ó de sus herederos, ella muerta, tomar las arras ó dexarlas, y tomar todo lo que el marido la hobo dado, siendo con ella desposado, lo qual hayan de escoger dentro de veinte dias despues de requeridos por los herederos del marido, y si no escogieren dentro del dicho término, que los dichos herederos escojan". (Ley 4. tit. 2. lib. 5. R.). Ley 54 de Toro, Vid. Libro X. De los contratos.... Titulo III. De las arras y dotes. Ley III. Modo de adquirir las arras disuelto el matrimonio en vida, o por muerte de alguno de los desposados.

67 "Si el marido mandare alguna cosa á su muger al tiempo de su muerte ó testamento, no se le cuente en la parte que la muger ha de haber de los bienes multiplicados durante el matrimonio, mas haya la dicha mitad de bienes, y la tal manda en lo que de Derecho debiere valer (ley 7. tit.9. lib. 5. R.)" Ley 16 de Toro. Vid. Libro X. De los contratos... Titulo IV. De los bienes gananciales, Ó adquiridos en el matrimonio. Ley VIII. Los bienes mandados por el marido á la muger, no se comprehendan en la mitad que ha de haber de los gananciales.

68 "Quando la muger renunciare las ganancias, no sea obligada á pagar parte alguna de las deudas que el marido hubiere hecho durante el matrimonio (ley .9. tit. 9. lib. 5. R.)" Ley 60 de Toro. Vid. Libro $X$. De los contratos.... Titulo IV. De los bienes gananciales, Ó adquiridos en el matrimonio. Ley IX. La muger, renunciando las ganancias, no pague las deudas hechas por el marido durante el matrimonio. 
La normativa referente a la disolución conyugal de los bienes gananciales permaneció vigente durante las centurias siguientes y corresponde, por tanto, a la desaparición del vínculo matrimonial por causa de fallecimiento. Durante el periodo histórico analizado, la separación voluntaria entre los cónyuges se contemplaba únicamente por motivos excepcionales (malos tratos, amancebamiento...) y de manera temporal, siempre buscando una reconciliación entre los esposos, de manera que la legislación no contempla la disolución del vínculo matrimonial en tales circunstancias ${ }^{69}$.

\section{CONCLUSIONES}

El análisis de la normativa histórica existente relativa a la regulación del matrimonio canónico, entre los siglos XVI y XIX, ofrece los siguientes resultados:

Por un lado, en los que respecta a las prohibiciones o restricciones para contraer matrimonio, es importante tener en cuenta que la clandestinidad fue consentida por la Iglesia y por la legislación civil hasta la segunda mitad del siglo XVI, cuando las normas impuestas por el Concilio de Trento intensificaron las medidas de control para la celebración de matrimonios. A partir de entonces se prohíben los matrimonios clandestinos, siendo necesario que se celebraran en la Iglesia, por un párroco y ante la presencia de testigos. Tales directrices fueron fijadas, en 1563, en el Decreto Tametsi e implicaban también la necesidad de consentimiento paterno para los novios y el registro parroquial, para que se certificara el casamiento.

Un elemento importante para concertar matrimonio va a ser el consentimiento paterno. Ya desde el periodo medieval la legislación contemplaba la

69 Durante el Antiguo Régimen existía la separación y el divorcio, pero no tal y como lo entendemos en la actualidad. En circunstancias excepcionales de conflicto entre los esposos se contemplaba la separación, pero esta era una separación de lecho, mesa y casa y tenía un carácter temporal. Se profundiza en la cuestión relativa al divorcio a finales del siglo XVIII y el siglo XIX en: Maire Adèlaide Costa, Conflictos matrimoniales y divorcio en Catalunya: 1775-1883 (Tesis doctoral, Universitat Pompeu Fabra, 2008), 189, https://www.tdx.cat/handle/10803/7471;jsessionid=2Co88DDF1CDo885F86CF9B3264785A07 
necesidad de que los novios acudieran libremente al matrimonio, lo cual se vio continuado en la legislación de finales del Antiguo Régimen. Será a partir del periodo moderno cuando se haga hincapié también en la aprobación por parte de los padres de los jóvenes. En este sentido, cabe destacar las normas que fueron promulgadas a finales del siglo XVIII para intentar frenar los matrimonios desiguales entre los hijos de familias acomodadas, así como se aplicaba también a las familias más humildes. La legislación, así pues, establecía la obligatoriedad de que los menores de 25 años tuvieran el consentimiento del padre, de manera previa al casamiento y, en su defecto, establece el orden de prelación, que recae sucesivamente en la madre viuda, los abuelos, tutores y curadores. En caso de incumplir las normas impuestas, ellos y sus descendientes perderían todos sus derechos civiles, relativos a la dote y la legítima paterna, a suceder como herederos forzosos en los bienes libres y demás herencia de padres y abuelos. Asimismo, la evolución de la normativa a principios del siglo XIX redujo la edad de los menores para pedir consentimiento, siendo hasta los 22 años para varones y 20 para mujeres, en las circunstancias en las que carecieran de familiares cercanos a quienes pedir permiso; pero ya no obligaba a los padres a dar una razón justificada en caso de que su respuesta a la petición de consentimiento por los hijos fuera negativa.

Por otro lado, en lo que respecta al patrimonio conyugal, la tradición histórica española, ya desde el periodo medieval, contemplaba la igualdad en el reparto de los bienes entre ambos miembros del matrimonio. No obstante, como paso previo al enlace y requisito para el contrato matrimonial se producía la redacción de la carta de dote o donación propter nuptias, que consistía en el inventario de los bienes que se le adelantaban a la novia de la legítima paterna. Por su parte, el varón aportaba las arras y estas no podían constituir más de la décima parte de sus bienes, tal y como se contempla en las Leyes de Toro y se mantiene durante todo el periodo moderno. En función de la riqueza de las familias las cantidades adelantadas podían ser variables, por lo que las leyes promulgadas entre los siglos XVI y XVII trataban de evitar que los padres se endeudaran para poder casar a las hijas, mientras que en el siglo XVIII los gastos de la boda no podían sobrepasar la octava parte del montante de la dote. 
En lo relativo a la gestión de los bienes gananciales, Felipe II, en 1566, aprobó nuevas leyes en las que mantuvo como bienes comunes todos aquellos que tuviera el marido y la mujer, salvo que uno de ellos probara la pertenencia exclusiva de parte de ellos. Los frutos y rentas obtenidos durante el matrimonio pertenecerían a ambos a partes iguales. Esta forma de reparto conyugal se va a mantener en los siglos siguientes en España, si bien existe una excepción, pues en Córdoba las mujeres casadas no tenían permitido participar en los gananciales que habían sido adquiridos durante el matrimonio.

Una vez disuelto el vínculo matrimonial, tras la muerte de uno de los esposos, se disolvía también la sociedad conyugal. Sobre esta cuestión, la legislación del siglo XV contemplaba la posibilidad de las segundas nupcias por parte de la viuda, si bien esta debería vivir honradamente, pues de lo contrario perdería su parte de los bienes. Posteriormente, la Ley 14 de Toro, en 1505, recogía la posibilidad de que el cónyuge supérstite dispusiera de los bienes gananciales del primer matrimonio, aunque hubiera contraído segundas o terceras nupcias. Mientras que los bienes que el cónyuge supérstite recibiera del difunto por vía testamentaria a modo de manda, se contarían de manera separada de su mitad correspondiente a los bienes gananciales. Además, la mujer tenía que reservar para los hijos de su esposo difunto la propiedad o usufructo de los bienes paternos.

Para concluir, se observa cierta homogeneidad en el desarrollo normativo del periodo analizado, donde apenas se producen cambios significativos entre los siglos XVI y XVIII. Se perciben también ciertas restricciones para las mujeres en el reparto de los bienes gananciales y en la segundo nupcialidad, que no se mencionan para los varones.

\section{REFERENCIAS BIBLIOGRÁFICAS}

Acuña-Guirola, Sara. "La forma del matrimonio hasta el Decreto Ne Temere". Ius Canonicum XIII 25 (1973): 137-190,https://dialnet.unirioja.es/servlet/articulo?codigo $=4607442$

Arbiol, Antonio. La familia regulada. Zaragoza: Institución “Fernando el Católico”, 2000. 
Arechederra Aranzadi, Luis Ignacio. "El matrimonio informal. (Nadie puede querer, lo que realmente quiere, sin quererlo)”. Revista chilena de derecho 21, $\mathrm{n}^{\circ} 2$ (1994): 227-231, https://dialnet.unirioja.es/servlet/articulo?codigo=2649868

Arellano Ayuso, Ignacio y Jesús María Usunáriz Garayoa (eds.). El matrimonio en Europa y el mundo hispánico. Siglos XVI y XVII. Madrid: Visor, 2005.

Blanco Carrasco, José Pablo. "Notas sobre la desobediencia intergeneracional durante los últimos compases de la España Moderna”. Tiempos modernos: Revista Electrónica de Historia Moderna 9, $\mathrm{n}^{\mathrm{o}} 38$ (2019): 323-344. https://dialnet.unirioja.es/servlet/articulo?codigo=7004493

Bolufer Peruga, Mónica. Amor, matrimonio y familia: la construcción histórica de la familia moderna. Madrid: Síntesis, 1998.

Bolufer Peruga, Mónica. "Las ambigüedades del sentimiento: el amor conyugal en textos del XVIII". En Antiguo Régimen y Liberalismo. Homenaje a Miguel Artola. Editado por Pablo Fernández Albaladejo y Margarita Ortega López. 429-438. T.3. Madrid: Alianza Editorial, Ediciones de la Universidad Autónoma de Madrid, 1994.

Costa, Maire Adèlaide. Conflictos matrimoniales y divorcio en Catalunya: 1775-1883. Tesis doctoral, Universitat Pompeu Fabra, 2008. https://www.tdx.cat/handle/10803/ 7471;jsessionid=2Co88DDF1CDo885F86CF9B3264785Ao7

De la Pascua, María José. "Una aproximación a la historia de la familia como espacio de afectos y desafectos: el mundo hispánico en el setecientos". Chronica Nova 27 (2000): 131-166. https://dialnet.unirioja.es/servlet/articulo?codigo $=67713$

Fernández Ucelay, Demetrio. "La evolución histórica de las formas de extinción del vínculo matrimonial”. Revista de Jurisprudencia. Lefebvre. El derecho 1 (Febrero de 2018) (en línea) https://elderecho.com/la-evolucion-historica-de-las-formas-de-extinciondel-vinculo-matrimonial

Iglesia Ferreiros, Aquilino José. "Uniones matrimoniales y afines en el Derecho Histórico español”. Revista de Derecho Notarial 85-86 (1974): 71-107.

Jedin, Hubert. Historia del Concilio de Trento. Pamplona: Universidad de Navarra, 1975.

López-Cordón, María Victoria y Montserrat Carbonell (eds.). Historia de la mujer e historia del matrimonio. Murcia: Universidad de Murcia, 1997.

Macías Domínguez, Alonso Manuel y María Luisa Candau Chacón. "Matrimonios y conflictos: abandono, divorcio y nulidad eclesiástica en la Andalucía moderna (Arzobispado de Sevilla, siglo XVIII)”. Revista complutense de historia de América 42 (2016): 119- 
146 (Ejemplar dedicado a: Dossier: Matrimonio en los siglos XVI-XVIII: derecho canónico, conflictos y realidad social)

DOI: http://dx.doi.org/10.5209/RCHA.53713

Pérez-Coca Sánchez-Matas, Carmen. "El sacramento del matrimonio en el sínodo placentino de 1534", Anuario de la Facultad de Derecho. Universidad de Extremadura 2 (1983): 371-408. https://dialnet.unirioja.es/servlet/articulo?codigo=813988

Tovar Pulido, Raquel. "Cultura material de la élite local española del siglo XVIII a través de la dote de doña Ana María Orozco y Venegas (Linares)”. En Investigaciones sobre Humanidades y Artes. Coordinado por Diana Arauz Mercado. Colección Pasado, Presente y Porvenir, Vol. VIII. 249-268. Zacatecas, México: Zezem Baltza Editores, 2020.

Tovar Pulido, Raquel. "Las repercusiones de la Guerra de Sucesión Española en la segunda nupcialidad y la movilidad geográfica: Ávila Meridional”. En Las segundas nupcias en la Edad Moderna: Una mirada a los límites del mercado matrimonial en España y Portugal. Coordinado por José Pablo Blanco Carrasco. 157-191. Madrid: Sílex, 2020.

Tovar Pulido, Raquel. "Mujeres en la jefatura del hogar, trabajo y riqueza patrimonial en Trujillo (Extremadura) en la segunda mitad del siglo XVIII". En De humilde e ilustre cuna: Retratos familiares de la España Moderna (siglos XV-XIX). Dirigido por Raquel Tovar Pulido. 153-178. Évora: CIDEHUS-Universidad de Évora, 2020.

Tovar Pulido, Raquel. "Casarse entre primos: matrimonios de conveniencia y consanguinidad en la España rural durante la época moderna (ss. XVII-XVIII)”. Revista de Historia Social y de las Mentalidades 2 (2019): 215-247 (Ejemplar dedicado a: Migrations: Theory and History) DOI: https://doi.org/10.35588/rhsm.v 23i2.3590

Tovar Pulido, Raquel. "Nubentes e mobilidade geográfica em Portugal no século XIX (1800-1830): o concelho de Marvão”. Revista da Faculdade de Letras. Historia 9, no 1 (2019): 148-176. DOI: 10.21747/o871164X/hist9_1a7

Tovar Pulido, Raquel. "Escrituras testamentarias: la transmisión de bienes en la España Moderna”. En XII Congreso de la Asociación de Demografía Histórica. (Universidad de Oporto. Del 4 al 7 de septiembre de 2019) (en prensa).

Tovar Pulido, Raquel. "Viudas hacendadas y labradoras: la propiedad femenina en el noreste andaluz a mediados del siglo XVIII (el Reino de Jaén)”. En Nuevas perspectivas de investigación en Historia Moderna: economía, sociedad, política y cultura en el mundo hispánico. Coordinado por María Ángeles Pérez Samper y José Luis Betrán Moya. 317-331. Barcelona: Universidad de Barcelona y Universidad Autónoma de Barcelona, 2018. 
Tovar Pulido, Raquel. "La riqueza patrimonial de las familias de las viudas jiennenses en el siglo XVIII". Cuadernos de historia moderna 42, $\mathrm{n}^{\mathrm{o}} 1$ (2017): 195-220. DOI: https://doi.org/10.5209/CHMO.56660

Tovar Pulido, Raquel. "Población y estructura matrimonial en el territorio del Partido de Navalmoral a finales del Antiguo Régimen y segunda mitad del siglo XIX (1787-1887)”. En XXI Coloquios Histórico-Culturales del Campo Arañuelo. Dedicados a D. Ángel Sánchez Pascual, poeta, ganador del Premio Adonais en 1975. Coordinado por Domingo Quijada González. 181-201. Cáceres: Ayuntamiento de Navalmoral de la Mata, 2015 .

Raquel Tovar Pulido Área de Historia del Derecho Departamento de Derecho Privado Facultad de Derecho Universidad de Extremadura rtovarp@unex.es https://orcid.org/oooo-0001-5894-1362 